\title{
The ability of cover crops to reduce nitrogen and phosphorus losses from arable land in southern Scandinavia and Finland
}

\author{
H. Aronsson, E.M. Hansen, I.K. Thomsen, J. Liu, A.F. Øgaard, H. Känkänen, and B. Ulén
}

\begin{abstract}
This review summarizes current knowledge from the literature and experimental studies on the role of cover crops (CCs) in reducing nitrogen $(\mathrm{N})$ leaching and phosphorus (P) losses to waters under the marine and humid continental climate conditions of southern Scandinavia and Finland. Field leaching studies from 11 sites indicate that undersown ryegrass (Lolium spp.) CCs are robust, with average $\mathrm{N}$ uptake in aboveground CC biomass of 7 to $38 \mathrm{~kg} \mathrm{~N} \mathrm{ha}^{-1}$ (6.2 to $\left.34 \mathrm{lb} \mathrm{N} \mathrm{ac}{ }^{-1}\right)$. Use of CCs sown at harvest (e.g., crucifers) is restricted to southern Scandinavia for climate reasons. The mean relative reduction in $\mathrm{N}$ leaching reported for all CCs investigated was $43 \%$, but it ranged between $62 \%$ increase instead of a reduction after a red clover (Trifolium pratense) CC on a clay soil to a reduction of $85 \%$ to $89 \%$ with a perennial ryegrass CC on sandy soils in Denmark (36 to $51 \mathrm{~kg} \mathrm{ha}^{-1}$ [32 to $46 \mathrm{lb} \mathrm{ac}^{-1}$ ]). The data indicate that CCs do not substantially reduce total $\mathrm{P}$ losses by runoff and leaching. The effects of CCs on total P leaching varied between a relative increase of $86 \%$ and a decrease of $43 \%$. Climate conditions involving freezing-thawing during winter increased the risk of losses of dissolved P from CC biomass. CCs have been implemented to varying degrees into agri-environmental programs. They are mandatory in Denmark and subsidized in Norway, Sweden, and Finland. CCs are grown on $8 \%$ of arable land in Denmark, 5\% in Sweden, $1 \%$ in Finland, and $0.5 \%$ in Norway, but CC area is now increasing dramatically in Finland due to a new subsidy program. In all countries there is a need, and potential, for increased use of CCs, but there are several constraints, particularly reduced interest among farmers. There is a clear need to identify CC systems and develop implementation strategies for appropriate distribution of CCs on different soils and regions with respect to required reductions in $\mathrm{N}$ leaching and $\mathrm{P}$ losses. For this, more knowledge is required, especially about the effect of CCs on P losses (e.g., the effect of species with different partitioning between shoot and root biomass and the effects of CC systems with harvesting of biomass). There is also a need to devise balanced solutions for maintaining and increasing the frequency of CCs in crop rotations to exploit the possible benefits of CCs in reducing nutrient losses.
\end{abstract}

Key words: cover crop species—nitrogen leaching—perennial ryegrass—phosphorus leaching-phosphorus surface runoff

The eutrophication problems in inland and coastal waters have been important drivers for agri-environmental programs in the Nordic countries for many years. Pollution load compilations in the Nordic countries indicate that diffuse sources contribute almost half the riverine load of nitrogen $(\mathrm{N})$ and phosphorus $(\mathrm{P})$, of which $60 \%$ to $90 \%$ originates from agricultural land (Helcom 2011). For the Baltic Sea, one of the world's largest brackish water bodies, international protection efforts have been carried out within the framework of the Helsinki Convention, while the European Union (EU) Water Framework Directive requires management plans for the protection of all water bodies to be formulated (European Commission 2014a). Concerns about environmental issues in the Nordic countries have resulted in extensive research on cover crops, which has mainly focused on $\mathrm{N}$ leaching and the ability of cover crops to deplete soil mineral $\mathrm{N}$ during autumn. Therefore the term "catch crop" is often used (Thorup-Kristensen et al. 2003). However, in this review we use the term "cover crop" (hereafter referred to as CCs), which also includes the function of preventing soil erosion and related $\mathrm{P}$ losses (Øgaard 2015; Dabney et al. 2010).

Implementation of Cover Crops for Reduced Nitrogen Leaching and Phosphorus Losses. The use of CCs to reduce $\mathrm{N}$ leaching from agriculture varies between the Nordic countries, not only with respect to dissemination, but also implementation methods. In Denmark and southern Sweden, the use of CCs has been widely recommended in advisory programs and included in programs for $\mathrm{N}$ leaching reduction targets (e.g., the EU Water Framework Directive and Nitrates Directive) during recent decades. In Norway and Finland, CCs have not been as extensively used to date, except for a short period in Norway during 2000 to 2005. In Denmark, an extensive regulatory framework whereby CCs are mandatory has resulted in their use on $8 \%$ of agricultural land (tables 1 and 2). The area of CCs required on individual farms in Denmark is regulated by the main crop types and the animal stocking density, but the compulsory CC area can also be replaced with other measures. For example, $10 \%$ or $14 \%$ of the area with a following crop of cereals, peas (Pisum sativum), faba beans (Vicia faba), maize (Zea mays L.), or oilseed rape (Brassica napus) must be covered with a CC until October 20 , with $14 \%$ required on farms using animal manure at rates of over $80 \mathrm{~kg}$ total- $\mathrm{N} \mathrm{ha}^{-1}$ (71 $\mathrm{lb}$ total- $\mathrm{N} \mathrm{ac}^{-1}$ ). According to the Danish regulations for 2014 to 2015, the CC species permitted are undersown grasses, cereals, crucifers, and chicory (Cichorium intybus). Crucifer CCs can be sown after harvest, but

Helena Aronsson is a senior lecturer with extension duties and Barbro Ulén is a professor, both at the Department of Soil and Environment, Swedish University of Agricultural Sciences in Uppsala, Sweden. Anne Falk Øgaard is a senior researcher at the Environment division at the Norwegian Institute of Bioeconomy Research in Ås, Norway. Elly Moller Hansen and Ingrid Kaag Thomsen are senior researchers at the Department of Agroecology at Aarhus University in Tjele, Denmark. Hannu Känkänen is a senior researcher in the Division of Natural Resources and Bioproduction at the Natural Resources Institute in Jokioinen, Finland. Jian Liu is a postdoctoral scholar in the Department of Plant Science at Penn State University, Pennsylvania, USA. 
before August 20, while cereal CCs have to be established before August 1. Fertilizer application to CCs in autumn is not allowed in Denmark or the other Nordic countries. The Danish regulations also require a reduction of 17 or $25 \mathrm{~kg} \mathrm{~N} \mathrm{ha}^{-1}$ (15 or $22 \mathrm{lb} \mathrm{N} \mathrm{ac}^{-1}$ ) of the $\mathrm{N}$ fertilizer rate in the following year, depending on stocking density, in order to exploit the residual effects of the CC.

In Sweden and Finland, environmental subsidies within the EU Common Agricultural Policy (CAP) are used to encourage use of CCs. In Finland, the subsidies were increased substantially in 2015, from 52 to $100 € \mathrm{ha}^{-1}$ (US $\$ 23$ to US $\$ 45$ $\mathrm{ac}^{-1}$ ), which has greatly increased farmers' interest. Both undersown and aftersown (before August 10) CCs are allowed with a variety of species, including grasses, crucifers, and legumes. In Sweden, the use of CCs has been promoted intensively since 2000 in advisory campaigns combined with subsidies. These are targeted at regions with a high risk of $\mathrm{N}$ leaching, including those identified as vulnerable zones within the EU Nitrates Directive (European Commission 2014b). This means that for those areas, the proportion of arable land with CCs is higher, up to $20 \%$, than the $5 \%$ average for the whole country (table 2). The Swedish CC subsidy can be combined with a subsidy for spring tillage, and about half the CC area is plowed in spring and the rest after October 10 to 20. Undersown grasses $(10 \%$ legumes permitted based on seed weight) are the dominant species, but for some regions crucifers sown after harvest were recently included in the subsidies. In Sweden, Denmark, and Finland, herbicide treatment is allowed, but not until the dates given in table 1, while in Norway the CC must be grown over winter.

In Norway, CCs have the dual purpose of reducing soil and $\mathrm{P}$ erosion and $\mathrm{N}$ leaching by providing a protective plant cover during autumn and winter and by $\mathrm{N}$ uptake, respectively. Subsidies for CCs were introduced in Norway in 1999, starting with a high rate (200€ ha $\mathrm{ha}^{-1}$ [US\$89 $\left.\mathrm{ac}^{-1}\right]$ ). However, this rate was later decreased and differentiated between vulnerable and nonvulnerable zones according to the EU Nitrates Directive, but also between types of CCs (i.e., with the lowest subsidies for undersown CCs and the highest for CCs sown after harvest of the main crop). CCs were grown on nearly $4 \%$ of arable land in Norway in 2002, but the area has since declined sharply (table 2), probably due to the lowered subsidies, risk of yield reductions, difficulties with weed control, and lack of suitable equipment for seeding CCs.

Constraints Set by Climate Conditions. Southern Scandinavia, including Denmark, and southern Finland are characterized by humid conditions, with mean annual precipitation between 400 and $700 \mathrm{~mm}$ (1.3 and $2.3 \mathrm{ft}$ ) in large parts of the region, but higher values, 1,000 to $3,000 \mathrm{~mm}$ (3.3 to 9.8 $\mathrm{ft})$, in western Norway and western Sweden. There is a marine climate in Denmark, southernmost Sweden, and coastal areas of Norway, and a humid continental climate in Finland, central Sweden, and inland Norway (Köppen 1936). Soils classified as erodible (e.g., clay soils with a low content of organic matter and poor structure [Lundekvam and Skøien 1998; Ulén et al. 2010]) dominate in southeast Norway, central Sweden, and Finland (Boardman and Poesen 2006), while high precipitation $\left(>900 \mathrm{~mm} \mathrm{y}^{-1}\left[3.0 \mathrm{ft} \mathrm{yr}^{-1}\right]\right.$ ) occurs most frequently on the west coast of Norway and Sweden.

In this region of the world, the period between harvest of the main annual crop and the first frost event of autumn is relatively short. The main crop is harvested from July to early September and the first frost normally occurs in September to October in inland areas of the region, and in November to December in southern and coastal areas. Cereal crops are important in the Nordic countries and occupy $22 \%$ to $55 \%$ of arable land. Winter cereals, predominantly winter wheat (Triticum aestivum L.), constitute about half the cereal crop area in Sweden and Denmark, but less than 10\% in Norway and Finland, where spring cereals such as barley (Hordeum vulgare L.) and oats (Avena sativa L.) dominate. The duration of the period between harvest and winter is very important for the risk of $\mathrm{N}$ leaching, especially if crop residues are incorporated into the soil in moist, warm conditions. After tillage in August or early September, N mineralization and accumulation of mineral $\mathrm{N}$ in the soil may be considerable (Lindén and Wallgren 1993; Känkänen et al. 1998; Torstensson 1998). This, in combination with low evapotranspiration during autumn and winter, high precipitation, and percolation of water through the soil, results in $\mathrm{N}$ leaching from the root zone (Thorup-Kristensen et al. 2003). Several Nordic studies have revealed that reduced, delayed, or omitted tillage during autumn, preferably in combination with a growing crop, reduces the risk of $N$ leaching substantially on soils susceptible to high $\mathrm{N}$ leaching (Hansen and Djurhuus 1997; Stenberg et al. 1999; Torstensson and Aronsson 2000). Using the short frost-free period during autumn efficiently for crop growth and $\mathrm{N}$ uptake places great demands on crop properties and management regime. A system where a frost-tolerant CC is undersown in the main crop in spring provides an excellent combination of rapid growth after harvest and no soil tillage during early autumn. Undersown CCs are most commonly used in spring cereals, and most studies to date have been performed in these systems; however undersowing of CCs is also practiced in winter cereals, maize, and oilseed rape. The Nordic climate restricts efficient use of CCs sown after harvest of the main crop to those main crops that are harvested early, such as vegetables, or in the southern parts of the region (Denmark, southern Sweden, and possibly southern Norway) after winter wheat, oilseed rape, or potatoes (Solanum tuberosum L.). Fertilization in autumn can increase CC value, but poses a risk of $\mathrm{N}$ leaching under Nordic climate conditions, where drain flow often occurs in October to April. Thus fertilization is considered to be incompatible with the CC concept (Hansen et al. 2000b).

The suitability of a CC species depends not only on the site-specific conditions, such as soil conditions, climate, and the cropping system in which the CC is grown, but also to a high extent on the desired function of the CC. There are several positive side-effects of CCs for the crop rotation, especially in the long term (e.g., increased soil organic matter content and soil structure, reduction of diseases, and weed control), although it is often difficult to fully explain and identify the reasons for observed effects due to the complexity of crop responses (Kirkegaard et al. 2008). There are also disadvantages of $\mathrm{CC}$ use that must be balanced against the gains (e.g., additional costs, yield losses, diseases, etc.; Dabney et al. 2001; Thorup-Kristensen et al. 2003). For example, the timing of nutrient release after incorporation of a CC, which is affected by time of incorporation, determines whether the CC nutrients become a resource for the crop rotation (Thorup-Kristensen 1993; Thorup-Kristensen and Dressbøll 2010). Moreover, improvements in soil fertility by frequent use of CCs will also contribute to a 
Table 1

General information about cover crop (CC) programs currently in use.

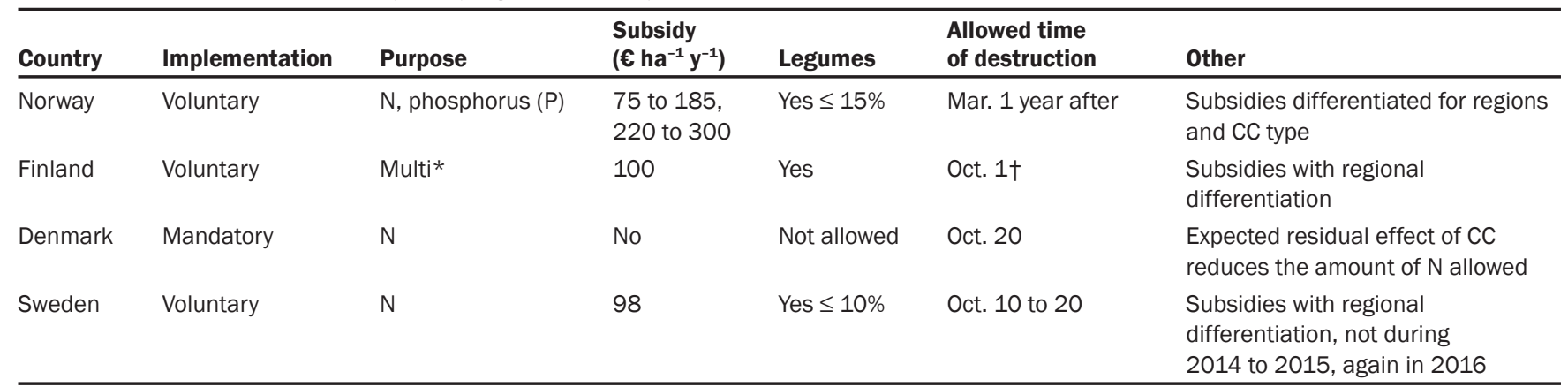

*Reduced nitrogen (N) leaching, reduced need for fossil energy and improved soil structure (Känkänen 2013).

†Herbicide treatment allowed from September 15.

\section{Table 2}

Cover crop (CC) area and associated estimated reduction in nitrogen (N) leaching from arable land on national level (Denmark 2011, Sweden 2011, Norway 2012, and Finland 2010). For Sweden, the CC area also includes land with a subsidy for spring tillage without a CC, which constitutes $10 \%$. For Norway, reduction by CCs was not determined (n.d.).

\begin{tabular}{|c|c|c|c|c|c|}
\hline Country & CC area (ha) & $\begin{array}{l}\mathrm{Cc}, \% \text { of } \\
\text { arable land }\end{array}$ & $\begin{array}{l}\text { Reduction of } \mathbf{N} \\
\text { leaching by } \mathrm{CC}\left(\mathrm{t}^{-1}\right)\end{array}$ & $\begin{array}{l}\text { Total } \mathbf{N} \\
\text { leaching }\left(\mathbf{t ~ y}^{-1}\right)\end{array}$ & Publication \\
\hline Norway & 4,400 & 0.5 & n.d. & 29,000 & $\begin{array}{l}\text { Bye et al. } 2014 \\
\text { NIVA } 2013\end{array}$ \\
\hline Finland & $23,000 *$ & 1 & 150 & 34,000 & $\begin{array}{l}\text { Tike } 2011 \\
\text { Vuorenmaa et al. } 2002 \\
\text { Salo and Turtola } 2006 \\
\text { Lemola et al. } 2014\end{array}$ \\
\hline Denmark & 211,000 & 8 & 6,975 & 165,000 & Børgesen et al. 2013 \\
\hline Sweden & 143,000 & 5 & 1,554 & 49,000 & $\begin{array}{l}\text { Blombäck et al. } 2014 \\
\text { Johnsson et al. } 2008\end{array}$ \\
\hline
\end{tabular}

somewhat increased risk of $\mathrm{N}$ leaching in the long term (Hansen et al. 2000a; Blombäck et al. 2003). For Nordic conditions, KarlssonStrese et al. (1996) defined an ideotype of undersown CCs for reduced $\mathrm{N}$ leaching and screened possible species. Important criteria for selection were those expected to be related to the effect on $\mathrm{N}$ leaching, without any negative influence on the yield of the main crop and without becoming a weed or contributing to an increase in pests. This describes fairly well the context for CCs in southern Scandinavia and Finland, where the water quality issue is the main question and where CCs are implemented within a legal framework and/or by subsidies.

Aim. Against this background, the aim of this paper was to review existing knowledge of CC species suitability and of the ability of $\mathrm{CCs}$ to reduce $\mathrm{N}$ leaching and $\mathrm{P}$ losses from arable land under the climate conditions in southern Scandinavia and Finland.The effect of CCs on $\mathrm{N}$ and $\mathrm{P}$ losses through leaching and surface runoff was evaluated at field level and, for $\mathrm{N}$, also at national level. The review combined a qualitative literature study of CC species and their $\mathrm{N}$ uptake during autumn with a meta-analysis of CC effects on measured $\mathrm{N}$ leaching and $\mathrm{P}$ losses.

\section{Materials and Methods}

The qualitative literature study of CC species and their $\mathrm{N}$ uptake during autumn summarized experiences from Nordic studies performed from the early 1990s, when such research began, until today. To review the effect of CCs on $\mathrm{N}$ leaching, studies that measured the $\mathrm{N}$ content in water draining from soils under field conditions and that permitted comparisons between treatments with and without CCs were selected (table 3). Measured changes in $\mathrm{N}$ leaching for each study were presented as absolute and relative values, together with information about soil type, fertilizer amounts, and tillage management. This included 16 different soils at 11 experimental sites, in studies lasting 1 to 17 years (table 3). These studies were mainly performed in Denmark and Sweden, but a few studies originate from Norway and Finland. The experimental work described was performed in separately tile-drained field plots, plots with ceramic suction cups, or lysimeters. Most of the work is published in international peer-reviewed journals, but data from some studies or parts of studies at sites in Sweden and Denmark have previously only been published in internal reports.

The upscaling of CC effects on $\mathrm{N}$ leaching to national level was based on published studies that estimated $\mathrm{N}$ leaching from arable land. For Sweden, the normalized leaching losses were estimated based on a Nutrient Leaching Coefficient Calculation System (NLeCCS) involving the SOILNDB simulation model and agricultural statistics from 
the national survey system (Johnsson et al. 2008). For Denmark, estimated losses were based on actual area with stocking density below or above $80 \mathrm{~kg}$ total-N ha ${ }^{-1}(71 \mathrm{lb}$ total- $\mathrm{N} \mathrm{ac}^{-1}$ ) and a weighted average value for the effects of CCs grown there (Børgesen et al. 2013). These average values were estimated from experiments (Hansen and Thomsen 2013). For Finland, the current reduction was estimated based on published data on average $\mathrm{N}$ leaching and the estimated effect of different CC species (Vuorenmaa et al. 2002; Salo and Turtola 2006; Tike 2011; Lemola et al. 2014). Total N leaching load for Norway was estimated using the TEOTIL model with coefficients based on data from the Norwegian agricultural environmental monitoring program JOVA (NIVA 2013), but estimates for reductions in $\mathrm{N}$ leaching by CCs were not available.

For P losses, there are considerably less field experimental data. Except for some studies of runoff from grassed buffer zones, we found CC leaching and runoff studies under field conditions at only six different soils at six experimental sites (table 4), all of them in Sweden. We also included lysimeter studies of P leaching from three Swedish soils after freezing-thawing events of different CCs (table 5).

\section{Results and Discussion}

Cover Crop Species Suitability and Nitrogen Uptake. The suitability of various species as undersown CCs has been tested in spring cereals, and according to Karlsson-Strese et al. (1996) and Känkänen and Eriksson (2007), grasses constitute a robust group for Nordic conditions. The Lolium species perennial ryegrass (L. perenne L.), Italian ryegrass (L. multiflorum Lam.), and annual ryegrass (L. multiflorum Lam. var westerwoldicum) are of special interest and are the most commonly used CCs in practical agriculture and field trials, with perennial ryegrass clearly dominating. Perennial ryegrass does not produce seeds during the first year, usually survives the winter (in contrast to the other two Lolium species), and is not overcompetitive. The yield reduction due to perennial ryegrass undersown at the same time or shortly after the main crop, with seed rate 7 to $10 \mathrm{~kg} \mathrm{ha}^{-1}\left(6.2\right.$ to $\left.8.9 \mathrm{lb} \mathrm{ac}^{-1}\right)$, is usually less than 3\% (Jensen 1991; Andersen and Olsen 1993; Wallgren and Lindén 1994; Valkama et al. 2015), whereas it is between $5 \%$ and $20 \%$ when using Italian or annual ryegrass (Andersen and Olsen 1993; Lewan 1994; Breland 1996b; Lyngstad and Børresen 1996; Ohlander et al. 1996; Känkänen and Eriksson 2007). Other grasses of interest for undersowing, but still not widely used, are rye fescue (Festulolium braunii L.; NilsdotterLinde et al. 1994), cocksfoot (Dactylis glomerata L.; Bergkvist et al. 2002), timothy (Phleum pratense L.; Känkänen and Eriksson 2007), and meadow fescue (Festuca pratensis L.; Känkänen and Eriksson 2007). Red fescue (Festuca rubra L.) exhibits slow growth, but Bergkvist et al. $(2002,2010)$ found it to be a suitable CC for autumn undersowing in winter wheat, due to low reduction of main crop yield in combination with satisfactory growth during autumn. Chicory as an undersown $\mathrm{CC}$ is attracting some interest due to its deep root system and its high rotational value, as it has low affinity with cereal crops. Chicory has been tested in some Swedish experiments, which found that the growth potential during autumn was lower (Myrbeck et al. 2012a) or comparable to that of perennial ryegrass, but that crop establishment was uncertain in two years out of three (Bergkvist et al. 2002). In Danish experiments, chicory established well when undersown in maize (Pedersen and Pedersen 2013). Dyer's woad (Isatis tinctoria L.) is another CC that has been successfully tested with respect to autumn growth (Munkholm and Hansen 2012).

Combining two or more different CC species enables a combination of desired properties to be obtained and may increase the probability of a good CC and efficient soil mineral $\mathrm{N}$ depletion, due to differences in growth between species. In a Finnish study by Känkänen and Eriksson (2007), a $\mathrm{CC}$ mixture of timothy and Italian ryegrass proved to be efficient in using the time available for crop growth, as $\mathrm{N}$ uptake in the Italian ryegrass was highest in autumn, while timothy took over in spring. Mixtures of red or white clover (Trifolium pratense L., Trifolium repens L.) and grasses (e.g., perennial ryegrass) are widely used as a CC in Sweden. Several studies have shown that undersown clover/grass mixtures with seed proportions of $10 / 90$ by weight can reduce soil mineral $\mathrm{N}$ content and leaching to the same extent as a pure grass CC (Bergkvist et al. 2011; Neumann et al. 2011; Aronsson et al. 2014). The use of legumes in pure stands as CCs for reduced $\mathrm{N}$ leaching has to date not been common practice in Scandinavia and Finland, since numerous studies have shown that their effectiveness in depletion of soil $\mathrm{N}$ is not reliable (Thorup-Kristensen 1994; Breland 1996a; Ranells and Wagger 1997; Känkänen et al. 2003; Askegaard and Eriksen 2008; Möller and Reents 2009; Bergkvist et al. 2011). Leguminous CCs that have been tested under Nordic climate conditions, undersown or sown after harvest, include the clovers (T. repens L., T. pratense L., and T. resupinatum L.) and also black medic (Medicago lupulina L.), hairy vetch (Vicia villosa L.), birdsfoot trefoil (Lotus corniculatus L.), and common vetch (Vicia sativa L.). Power and Zachariassen (1993) found that hairy vetch had higher $N$ content in biomass under cool conditions than several other legumes. Moreover, Brandsaeter et al. (2008) investigated biomass production and winter survival of different leguminous CCs and found hairy vetch, which is a biennial crop, to be frost-resistant and suitable for Norwegian conditions.

Winter cereals and crucifers (e.g., white mustard [Sinapis alba L.] and oilseed radish [Raphanus sativus L.]) are commonly used as CCs sown shortly before or after harvest of the main crop. Honey herb (Phacelia tanacetifolia L.) has attracted some interest as a CC after harvest, as has hairy vetch. In regard to the crucifers, Danish studies, supported by unpublished Swedish data, have concluded that CCs sown after harvest of the main crop need to be sown in early August in order to have enough time for growth (Hansen et al. 2000b). A major consideration with these crops is that dry conditions in late summer can prevent or delay germination. Preharvest broadcasting of seeds about two weeks before harvest can extend the growing season of the CC, compared with when seeds are incorporated by shallow cultivation after harvest of the main crop (Munkholm and Hansen 2012; Thomsen and Hansen 2014).

The capacity of a CC for vigorous autumn growth determines its capacity for nutrient uptake and thereby depletion of available soil N. A high capacity for soil $\mathrm{N}$ depletion minimizes the risk of $\mathrm{N}$ leaching when large amounts of mineralized $\mathrm{N}$ or residual $\mathrm{N}$ from fertilizer or manure are left in the soil. In Nordic studies, the mean $\mathrm{N}$ content in aboveground biomass of undersown perennial ryegrass in late autumn is reported to vary between 7 and $38 \mathrm{~kg} \mathrm{~N} \mathrm{ha}^{-1}$ (6.2 and $\left.34 \mathrm{lb} \mathrm{N} \mathrm{ac}{ }^{-1}\right)$ when no autumn fertilizer is applied (Thomsen et al. 1993; Hansen and 
Djurhuus 1997; Torstensson and Aronsson 2000; Aronsson et al. 2003; Aronsson and Torstensson 2003, 2009). This involves biomass production of up to $1,500 \mathrm{~kg}$ dry matter ha $\mathrm{a}^{-1}\left(3,300 \mathrm{lb}\right.$ dry matter $\left.\mathrm{ac}^{-1}\right)$. When fertilized in autumn, ryegrass CCs have been found to reach $\mathrm{N}$ contents of $76 \mathrm{~kg} \mathrm{~N} \mathrm{ha}{ }^{-1}$ $\left(68 \mathrm{lb} \mathrm{N} \mathrm{ac}^{-1}\right), 47 \mathrm{~kg} \mathrm{~N} \mathrm{ha}^{-1}$ (42 $\mathrm{lb} \mathrm{N} \mathrm{ac}^{-1}$ ), and $30 \mathrm{~kg} \mathrm{ha}^{-1}\left(27 \mathrm{lb} \mathrm{N} \mathrm{ac}^{-1}\right)$ in Danish (Simmelsgaard 1991) and Swedish (Aronsson et al. 2003) studies, respectively. Undersown CCs of timothy, red fescue, and cocksfoot have been shown to be less efficient in taking up $\mathrm{N}$ during winter, with $9 \mathrm{~kg} \mathrm{~N} \mathrm{ha}{ }^{-1}(8 \mathrm{lb}$ $\mathrm{N} \mathrm{ac}^{-1}$ ) in timothy (Känkänen and Eriksson 2007) and $12 \mathrm{~kg} \mathrm{~N} \mathrm{ha}^{-1}\left(11 \mathrm{lb} \mathrm{N} \mathrm{ac}^{-1}\right)$ in red fescue (Aronsson and Torstensson 2009). Crucifers sown after harvest, such as oilseed radish and white mustard, show wide variation in growth and $\mathrm{N}$ uptake. According to a Danish evaluation of CCs (Hansen et al. $2000 \mathrm{~b}$ ), time of sowing and $\mathrm{N}$ availability are very important factors. In that study, an aboveground $\mathrm{N}$ content of 27 to $77 \mathrm{~kg} \mathrm{ha}^{-1}$ ( 24 to $69 \mathrm{lb} \mathrm{ac}^{-1}$ ) was recorded when the CCs were sown in August, but there was great variation due to varying conditions for germination in different years. Time of sowing is also very important for other autumnsown CCs, such as cereals, and may be the determining factor in whether a CC has any effect at all. This was the conclusion reached by Lindén et al. (2000), who summarized the data from 70 observations of $\mathrm{N}$ uptake in winter wheat, winter rye (Secale cereale L.), and triticale (Triticum secale L.) in Sweden during an eight-year period. They concluded that sowing in October gave negligible $\mathrm{N}$ uptake, while sowing in early and mid-September resulted in $\mathrm{N}$ uptake in aboveground biomass of 20 and $30 \mathrm{~kg} \mathrm{ha}^{-1}$ (18 and $27 \mathrm{lb}$ $\left.\mathrm{ac}^{-1}\right)$, respectively.

Cover Crop Effects on Nitrogen Leaching at Field Level. The CC used in the leaching studies presented in table 3 was mainly perennial ryegrass undersown in spring cereals, which performs successfully as a CC in the Nordic region, reducing mineral $\mathrm{N}$ accumulation and $\mathrm{N}$ leaching. However, Italian ryegrass, crucifers, red fescue, and red clover were also included. The CCs in the field trials were incorporated in either late autumn or spring. For most of the comparisons, the same time of tillage was used for the CC treatment and the control, which allowed direct evaluation of the CC effect. In some cases, the Swedish studies at the Fotegarden and Mellby sites and the Danish study reported by Eriksen et al. (2008), the CC treatment was plowed under in spring, while the control was plowed under in autumn for comparison with common agricultural practice. Therefore in these studies, the CC effect also included the effect of delayed tillage. Some of the experiments used CCs repeatedly, and thus the long-term effects of the CCs on soil fertility were included in the results obtained.

The relative reduction in $\mathrm{N}$ leaching varied between none and $89 \%$ (mean 43\%), although in one experiment with red clover as the $\mathrm{CC}$ the $\mathrm{N}$ leaching increased considerably (Sweden/Lanna; Lindén et al. 1993). For all undersown grasses, the mean $\mathrm{N}$ reduction was $48 \%$. In some cases (Stenberg et al. 1999), low reduction rate was attributable to poor development of the CC. The data clearly demonstrate that CCs, especially undersown grasses, were able to reduce $\mathrm{N}$ leaching considerably at all study sites and soils, but also that the effect varied widely. Some of the clay, silt, and loam soil sites had relatively low losses, even without CCs, resulting in low absolute changes in $\mathrm{N}$ leaching due to the CC. The highest absolute reductions in $\mathrm{N}$ leaching, up to $51 \mathrm{~kg} \mathrm{ha}^{-1}\left(46 \mathrm{lb} \mathrm{ac}^{-1}\right)$, were found for sandy soils in Denmark (Eriksen et al. 2008). Incorporation of CCs in spring in general gave a larger reduction than autumn incorporation, but with exceptions (Lemola et al. 2000). The long-term studies with a CC every year for 17 years at Mellby showed that no autumn tillage combined with a CC was important for reducing $\mathrm{N}$ leaching even from a soil without $\mathrm{N}$ applications for many years, where the average relative reduction was 55\% (Torstensson et al. 2006; Aronsson and Torstensson 2009). The CCs at the Mellby site had the capacity for increased growth and soil $\mathrm{N}$ depletion following application of moderate rates of slurry in spring, while application of excessive amounts of slurry in spring decreased the relative effect on $\mathrm{N}$ leaching of CCs from $55 \%$ to $25 \%$. During a few years in which studies of Italian ryegrass and red fescue were carried out at the Mellby site, Italian ryegrass proved to reduce $\mathrm{N}$ leaching very effectively (Aronsson and Torstensson 2009), an effect also reported in Finnish studies of soil $\mathrm{N}$ depletion by CCs (Känkänen and Eriksson 2007). Red fescue was found to grow more slowly during autumn, and the effect on $\mathrm{N}$ leaching was considerably lower than for perennial ryegrass.

At one Swedish site, Lönnstorp, with a clay loam soil, a study comparing a ryegrass CC incorporated in autumn with winter wheat sown in autumn found that the reduction in $\mathrm{N}$ leaching by winter wheat was about half that of the CC $(23 \%$ compared with $43 \%$ ) during a 10-year period (Aronsson and Torstensson 2003). A study by Thomsen and Hansen (2014), which included oilseed radish or white mustard CC before winter wheat, found that white mustard was the more efficient of the two, but that the reduction in $\mathrm{N}$ leaching was only about half that when the CC was grown over winter. For winter cereals, there is often a need for seedbed preparation in autumn, which may counteract the $\mathrm{CC}$ effect due to the increased $\mathrm{N}$ mineralization caused by soil tillage. Myrbeck et al. (2012b) examined different strategies for winter wheat establishment, which included different types of tillage and time of sowing. They concluded that time of sowing of the wheat was more important than type of tillage for reducing soil mineral $\mathrm{N}$ in autumn, confirming previous findings by Lindén et al. (2000).

Cover Crop Effects on Nitrogen Leaching at National Level. The total $\mathrm{N}$ leaching from agriculture differs between the Nordic countries, due to differences in total amount of arable land and average annual area-specific load, which was recalculated from table 2 to be about $63 \mathrm{~kg} \mathrm{ha}^{-1}\left(56 \mathrm{lb} \mathrm{ac}^{-1}\right)$ in Denmark, $29 \mathrm{~kg} \mathrm{ha}^{-1}\left(26 \mathrm{lb} \mathrm{ac}^{-1}\right)$ in Norway, $18 \mathrm{~kg} \mathrm{ha}^{-1}$ $\left(16 \mathrm{lb} \mathrm{ac}^{-1}\right)$ in Sweden, and $15 \mathrm{~kg} \mathrm{ha}^{-1}(13$ $\left.\mathrm{lb} \mathrm{ac}^{-1}\right)$ in Finland. The average reduction in $\mathrm{N}$ leaching due to $\mathrm{CC}$ was estimated to be $33 \mathrm{~kg} \mathrm{ha}^{-1}\left(29 \mathrm{lb} \mathrm{ac}^{-1}\right)$ in Denmark, $11 \mathrm{~kg}$ $\mathrm{ha}^{-1}\left(9.8 \mathrm{lb} \mathrm{ac}^{-1}\right)$ in Sweden, and $6.5 \mathrm{~kg} \mathrm{ha}^{-1}$ $\left(5.8 \mathrm{lb} \mathrm{ac}^{-1}\right)$ in Finland. These figures reflect the range reported in field experiments on which the modeling is based (table 3 ). In both Sweden and Denmark, the reduction in $\mathrm{N}$ leaching brought about by CCs represents a considerable share of the national reduction target due to the substantial proportion of arable land used for CCs, $5 \%$ and 8\%, respectively. Calculations for Sweden have revealed that CCs, almost exclusively perennial ryegrass, and/or spring plowing contributed about $20 \%$ of the reduction achieved during a 10-year period (Johnsson et al. 2008). In relation to the total load from agriculture, however, the reduction by CCs constitutes only $3 \%$ to $4 \%$. 


\section{Table 3}

Change in average annual nitrogen $(\mathrm{N})$ losses in field experiments, in absolute $\left(\mathrm{kg} \mathrm{ha}^{-1}\right)$ and relative values $(\%)$, where $\mathrm{F}=\mathrm{drained}$ field plots, $\mathrm{L}=$ lysimeters, $\mathrm{C}=$ field plots with ceramic suction cups, and $n=$ number of years. Experiments with index ${ }^{\top}$ used total- $\mathrm{N}$ and index ${ }^{\mathrm{N}}$ used nitrate-N. Main crops were spring cereals and cover crops were undersown, unless otherwise stated. The control treatment had the same crop and fertilization, unless otherwise stated.

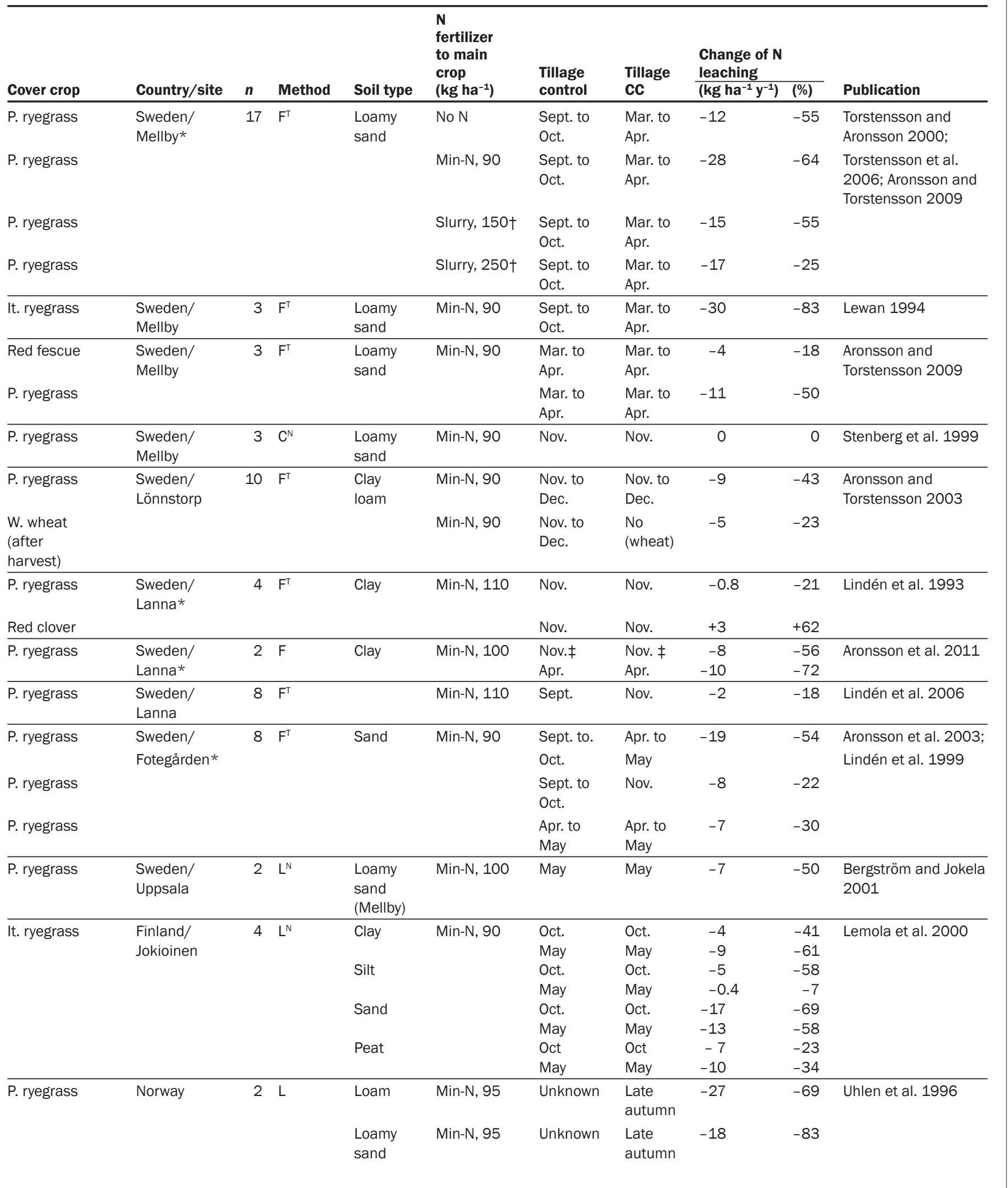


Table 3 continued

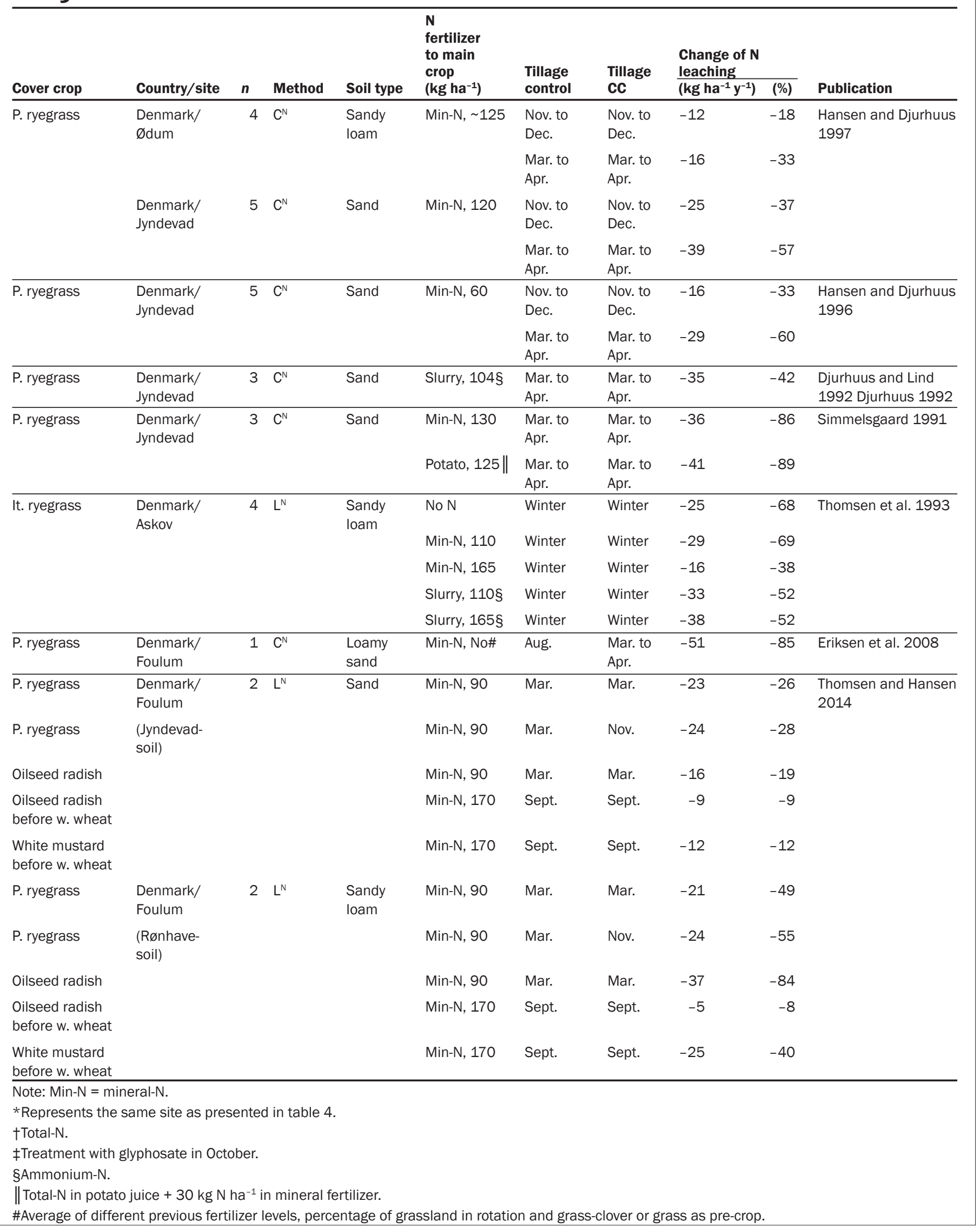


Potential for Increased Use of Cover Crops. Theoretically, the potential for increased use of undersown CCs is substantial in Scandinavia and Finland. For Sweden, potential CC area, based on actual cropping systems in 22 different regions, is an estimated 593,000 ha $(1,465,300 \mathrm{ac})$, which is about three times the actual area in 2011 (unpublished data). Due to differing types of crop rotations, the potential area differs between $8 \%$ and $33 \%$ in different regions. For sandy soils, where CCs have the largest effects, on average $62 \%$ of the total area could be used for CCs. The limitation on use of undersown CCs for growth until late autumn is primarily set by the following crop, which could not be grassland or autumn sown crops (e.g., winter wheat).

The compulsory CCs in Denmark pose restrictions on the present choice of crop and it is assumed that the area with spring cereals is larger than actually wanted by farmers as the standard CCs must be followed by a spring sown crop. Still, based on the present crop occurrence it has been estimated (unpublished data) that the area of CC could potentially be twice that in 2011 (i.e., over 400,000 ha [990,000 ac]). In both Sweden and Denmark, winter cereals are important cash crops that cover $20 \%$ to $35 \%$ of arable land, corresponding to about half of the total cereal area. This restricts the possibilities to use CCs until late autumn or over winter, since winter cereals are sown during September to October. In the Danish program, where CCs are mandatory, a solution to avoid undesired limitations on winter cereal production is included whereby CCs before winter cereals are allowed with the requirement that a larger area be used in order to account for a lower effect on $\mathrm{N}$ leaching, as shown by Thomsen and Hansen (2014). Engström et al. (2011) also found that undersown ryegrass CCs incorporated before sowing of winter wheat reduced $\mathrm{N}$ leaching, at least in one year with a mild winter in Sweden.

For Norway, the estimated potential area of CCs is much larger than used today, 176,000 ha $(434,400 \mathrm{ac})$ compared with 4,400 ha $(10,872 \mathrm{ac})$, which corresponds to $60 \%$ of the total area of cereals. These calculations were carried out using six-year mean values of crop statistics for counties with a significant cereal production as
Total area of cereals - (Area of winter cereals

$\times 2)-($ Total area of grassland $\div 4)$,

where the grassland was assumed to be tilled every four years and reestablished by undersowing in spring cereals.

In Finland, a project investigating the opportunities for replacement of fossil fuelbased fertilizers has revealed that about 360,000 ha $(889,600 \mathrm{ac})$ of arable land could be used for undersown CCs (Känkänen et al. 2013). Preliminary figures for 2015 indicate that the new program for CC subsidies in Finland is attracting considerable interest and that the CC area has increased by about 10 -fold compared with that in 2010, which was 23,000 ha $(56,800 \mathrm{ac})$.

Cover Crop Effects on Phosphorus Losses at Field Level. In Norway, there are considerable erosion problems due to a combination of soils with low aggregate stability, sloping fields, and snowmelt periods. Data from the Norwegian Agricultural Environmental Monitoring Program JOVA show that average soil losses during a period of 12 to 20 years for five small agricultural catchments dominated by arable crops varied between 192 and 3,130 kg ha ${ }^{-1} \mathrm{y}^{-1}$ (171 and 2,795 $\left.\mathrm{lb} \mathrm{ac} \mathrm{yr}^{-1}\right)$. The related losses of total $\mathrm{P}$ varied between 0.51 and $7.5 \mathrm{~kg} \mathrm{P} \mathrm{ha}^{-1} \mathrm{y}^{-1}$ (0.46 and $\left.6.6 \mathrm{lb} \mathrm{ac}^{-1} \mathrm{P} \mathrm{yr}^{-1}\right)$ and the losses of dissolved $\mathrm{P}$ between 0.18 and $1.0 \mathrm{~kg} \mathrm{P} \mathrm{ha}{ }^{-1}$ $\mathrm{y}^{-1}\left(0.16\right.$ and $\left.0.92 \mathrm{lb} \mathrm{ac}^{-1} \mathrm{P} \mathrm{yr}^{-1}\right)$ (Bechmann and Øygarden 2013; Bechmann et al. 2013). According to model estimations of annual $\mathrm{P}$ losses by erosion and leaching for different regions in Sweden (Johnsson et al. 2008), P losses were 0.08 to $1.3 \mathrm{~kg} \mathrm{ha}^{-1}$ (0.07 to $1.2 \mathrm{lb}$ $\left.\mathrm{ac}^{-1}\right)$ of total $\mathrm{P}$ and 0.04 to $0.34 \mathrm{~kg} \mathrm{ha}^{-1}(0.04$ to $0.30 \mathrm{lb} \mathrm{ac}^{-1}$ ) of dissolved P. Losses of particulate $\mathrm{P}$ by erosion were estimated to vary between 0.009 and $0.27 \mathrm{~kg} \mathrm{ha}^{-1} \mathrm{y}^{-1}(0.008$ and $0.24 \mathrm{lb} \mathrm{ac}^{-1} \mathrm{yr}^{-1}$ ), or $8 \%$ to $33 \%$ of the total losses of $\mathrm{P}$.

In one of the JOVA program catchments in Norway, with mainly cereal production on clay and silt soils, it is possible to analyze the effect of CCs on $\mathrm{N}$ and $\mathrm{P}$ losses, as the use of CCs increased from $0 \%$ to nearly $50 \%$ during 1999 to 2001, and thereafter gradually decreased. Subsidies were introduced in 1999 and there was an advisory campaign on the use of CCs, resulting in high adoption by farmers. Surprisingly, no reduction in N leaching in response to the area of CCs was observed, although there were reduced losses of $\mathrm{P}$ in field runoff (Bechmann et al. 2008).Vegetation during autumn and winter can reduce soil erosion and transport of particulate $\mathrm{P}$ on the soil surface, as shown by Ulén and Kalisky (2005) and Uusi-Kämppä (2008), who studied grass buffer zones, and CCs would probably also contribute to less $\mathrm{P}$ erosion from the soil surface and/or through macropores.

Avoidance of autumn plowing and adoption of spring plowing or no-till have been successful for reducing soil and $\mathrm{P}$ erosion losses in Norway (Lundekvam and Skøien 1998; Bechmann 2012), and also in Sweden (Ulén 1997; Ulén and Kalisky 2005). However, as shown in table 4, the total losses of $\mathrm{P}$ were not substantially reduced, or even increased, from soil with a CC growing over winter in Swedish studies of surface runoff. This was due to increased losses of dissolved P. The study summarized in table 5 included extraction of CC material grown in the greenhouse and exposed to repeated freezing-thawing and similar treatment of these CCs in topsoil lysimeters collected in the field (Liu et al. 2013). One of the soils used in that lysimeter study (Lanna clay) was also included in one of the experiments presented in table 4 . These results from different scales clearly illustrate that despite lysimeter studies indicating high potential for $\mathrm{P}$ release from CC material, this does not always result in increased transport of $\mathrm{P}$ through the soil under more natural conditions. For example, the amounts of water-extractable $\mathrm{P}$ in biomass oilseed radish and white mustard were among the highest recorded (table 5), but measured leaching through the topsoil lysimeters was moderate and losses to tile drains from a sandy soil were not increased compared with the control (table 4). This was also shown by Roberson et al. (2007), who made similar comparisons between lysimeter and field studies. Moreover, the most commonly used CC in Sweden, perennial ryegrass, showed considerable losses of $\mathrm{P}$ in the extraction study. For the Lanna field site (Lindén et al. 1993), a clover CC clearly increased the P leaching, but this was only partly verified in the lysimeter study. For chicory, the results from extraction and lysimeter measurements indicated lower losses than from perennial ryegrass. Other studies have also shown that cover crops can increase losses of dissolved $\mathrm{P}$ under the climate conditions prevailing in the Nordic countries, where the crop is often exposed to repeated freezing/thawing cycles during autumn and winter (Bechmann et al. 2005; 
Table 4

Change in average annual total $\mathrm{P}$ losses in field experiments $\left(\mathrm{F}=\right.$ drained field plots, $n=$ number of years), in absolute annual values $\left(\mathrm{kg} \mathrm{ha} \mathrm{a}^{-1}\right)$ and relative values (\%), compared with a control without a cover crop. The upper part of table shows leaching to subsurface drains; the lower part shows measurements of surface runoff. Main crops were spring cereals, and cover crops were undersown, unless otherwise stated.

\begin{tabular}{|c|c|c|c|c|c|c|c|c|c|c|}
\hline Cover crop & Country/site & $n$ & Method & Soil type & $\begin{array}{l}\text { P } \\
\text { fertilizer } \\
\text { to main } \\
\text { crop }\end{array}$ & $\begin{array}{l}\text { Tillage } \\
\text { control }\end{array}$ & $\begin{array}{l}\text { Tillage } \\
\text { CC }\end{array}$ & $\frac{\text { Change of } P}{\left(\mathrm{~kg} \mathrm{ha}^{-1} \mathrm{y}^{-1}\right)}$ & $\frac{\text { loss }}{(\%)}$ & Publication \\
\hline P. ryegrass & $\begin{array}{l}\text { Sweden/ } \\
\text { Mellby* }\end{array}$ & 17 & $\mathrm{~F}$ & $\begin{array}{l}\text { Loamy } \\
\text { sand }\end{array}$ & $\begin{array}{l}\text { Min-P 20, } \\
\text { ON }\end{array}$ & $\begin{array}{l}\text { Sept. to } \\
\text { Oct. }\end{array}$ & $\begin{array}{l}\text { Mar. to } \\
\text { Apr. }\end{array}$ & -0.11 & -43 & Liu et al. 2012 \\
\hline P. ryegrass & & & & & Min-P 20 & $\begin{array}{l}\text { Sept. to } \\
\text { Oct. }\end{array}$ & $\begin{array}{l}\text { Mar. to } \\
\text { Apr. }\end{array}$ & +0.09 & +86 & \\
\hline P. ryegrass & & & & & Slurry, 30 & $\begin{array}{l}\text { Sept. to } \\
\text { Oct. }\end{array}$ & $\begin{array}{l}\text { Mar. to } \\
\text { Apr. }\end{array}$ & +0.01 & +8 & \\
\hline P. ryegrass & & & & & Slurry, 60 & $\begin{array}{l}\text { Sept. to } \\
\text { Oct. }\end{array}$ & $\begin{array}{l}\text { Mar. to } \\
\text { Apr. }\end{array}$ & 0 & 0 & \\
\hline P. ryegrass & $\begin{array}{l}\text { Sweden/ } \\
\text { Lanna** }\end{array}$ & 2 & $\mathrm{~F}$ & Clay & Min-P, 10 & Nov. $†$ & Nov. $†$ & -0.22 & -27 & Aronsson et al. 2011 \\
\hline Red clover & & & & & No $P$ & Nov. & Nov. & +0.023 & +74 & \\
\hline P. ryegrass & $\begin{array}{l}\text { Sweden/ } \\
\text { Fotegården* }\end{array}$ & 8 & $\mathrm{~F}$ & Sand & Min-P, 20 & $\begin{array}{l}\text { Sept. to } \\
\text { Oct. }\end{array}$ & $\begin{array}{l}\text { Apr. to } \\
\text { May }\end{array}$ & -0.002 & -4 & Aronsson et al. 2003 \\
\hline P. ryegrass & & & & & & $\begin{array}{l}\text { Sept. to } \\
\text { Oct. }\end{array}$ & Nov. & +0.01 & +21 & \\
\hline P. ryegrass & & & & & & $\begin{array}{l}\text { Apr. to } \\
\text { May }\end{array}$ & $\begin{array}{l}\text { Apr. to } \\
\text { May }\end{array}$ & +0.02 & +43 & \\
\hline $\begin{array}{l}\text { Oilseed radish } \\
\text { after early } \\
\text { potatoes }\end{array}$ & $\begin{array}{l}\text { Sweden/ } \\
\text { Böslid }\end{array}$ & 3 & $\mathrm{~F}$ & Sand & Min-P, 40 & $\begin{array}{l}\text { S. barleył } \\
\text { Nov. to } \\
\text { Dec. }\end{array}$ & $\begin{array}{l}\text { Potatoes } \neq \\
\text { Nov. to } \\
\text { Dec. }\end{array}$ & 0 & 0 & Neumann et al. 2012 \\
\hline \multicolumn{11}{|c|}{ Measurements of surface runoff } \\
\hline White clover & $\begin{array}{l}\text { Sweden/ } \\
\text { Hedemora }\end{array}$ & 7 & & $\begin{array}{l}\text { Silty } \\
\text { clay } \\
\text { loam }\end{array}$ & Min-P 20 & $\begin{array}{l}\text { Oct. to } \\
\text { Apr. }\end{array}$ & $\begin{array}{l}\text { Oct. to } \\
\text { Apr. }\end{array}$ & -0.01 & -5 & \\
\hline
\end{tabular}

Sturite et al. 2007; Riddle and Bergström 2013; Øgaard 2015). On plot scale, increased concentrations of dissolved $\mathrm{P}$ from plots with undersown Italian ryegrass or white clover, especially in the first runoff after frost, were found in a study by Børresen and Uhlen (1991). This is probably one contributing factor to the increased concentrations of dissolved $\mathrm{P}$ in drainage water reported for grasslands and grass/clover crops (Aronsson et al. 2014; Turtola and Jaakkola 1995), although the opposite was found in the JOVA monitoring study described above. Comparison of winter $\mathrm{P}$ losses from white clover, Italian ryegrass, and meadow fescue under field conditions in the study by Sturite et al. (2007) showed that losses were lowest for meadow fescue.
Discussion. Measurements at field scale and estimates of reductions in $\mathrm{N}$ leaching from agricultural land at larger scale reveal that growing CCs can be an important measure to achieve reduction targets for $\mathrm{N}$ loads from agriculture under Nordic conditions. The published data also show great variation in the effect on $\mathrm{N}$ leaching depending on factors related to cropping methods and species 
used, as well as soil type and climate. The largest measured $\mathrm{N}$ leaching reductions by CCs are reported for sandy soils in southern parts of the Nordic region. However, on evaluating $\mathrm{N}$ leaching results from Nordic studies, including some of the studies presented here, Valkama et al. (2015) were unable to find significant differences in $\mathrm{CC}$ effects due to soil texture, country, or precipitation conditions.

Incorporation of CCs in spring has proven to give the most reliable reduction in $\mathrm{N}$ leaching in several studies, but incorporation of grass CCs in late autumn may be preferable with respect to $\mathrm{N}$ dynamics in the following growing season (Aronsson and Torstensson 1998). Manipulating time of incorporation in order to achieve a balance between soil mineral $\mathrm{N}$ depletion by a $\mathrm{CC}$ and $\mathrm{N}$ availability for the next crop is influenced by soil type and precipitation conditions, as discussed by Thorup-Kristensen (1993) and Thorup-Kristensen and Dressbøll (2010). However, the final decision on how and when to terminate a CC is often based on practical considerations. Incorporation may be convenient in spring on sandy soils, but on clay soils there is a risk of soil compaction when plowing in spring.

The conclusion for a clay soil (45\% clay) in Sweden was that the $\mathrm{N}$ leaching reduction by CC was often quite small in both absolute and relative figures. Structured clay soils may have less efficient water percolation, and some $\mathrm{N}$ may be retained over winter or lost by denitrification, as shown by Aronsson and Stenberg (2010), Myrbeck et al. (2012a, 2014), and Wetterlind et al. (2006). This demonstrates that CCs for reduced $\mathrm{N}$ leaching are not urgently needed for soils where only a minor part of soil mineral $\mathrm{N}$ is expected to be lost through leaching over winter (e.g., soils with high denitrification or low precipitation, as described by Thorup-Kristensen [1993]). In contrast to N leaching, for P losses clay soils may pose a considerable risk of both surface runoff and losses to subsurface drains, due to fast transport in macropores (Ulén et al. 2010). The field leaching studies on the Swedish clay soil at Lanna showed considerable relative reductions in $\mathrm{P}$ leaching on plots with a ryegrass CC. However, the lysimeter studies presented in table 5 showed that CC plant material can be a potential source of $\mathrm{P}$ transport when exposed to freezing-thawing events. This must be considered when evaluating the effect of CCs on erosion, since reduced ero- sion might be replaced by higher losses of dissolved P, as found in a Finnish study of grass buffers by Uusi-Kämppä (2008), where particulate P was reduced by $40 \%$, but dissolved $\mathrm{P}$ was increased by $60 \%$ compared to soil without grass buffers. The combined results from the field studies indicated that total P leaching may either increase or decrease in CC systems, although the soils presented in table 4 did not represent highrisk soils, since $\mathrm{P}$ leaching was low overall $\left(<0.1 \mathrm{~kg} \mathrm{ha}^{-1}\left[<0.09 \mathrm{lb} \mathrm{ac}^{-1}\right]\right)$, as were the absolute values of differences between treatments. The correlation between crop uptake of soluble $\mathrm{P}$ and leaching seems to be less clear than that for $\mathrm{N}$, as $\mathrm{P}$ leaching through the soil profile is highly dependent not only on a source factor, but also on the transport pathways present and the soil's capacity for sorption/desorption of P (Bergström and Shirmohammadi 1999; Djodjic et al. 2004). It is questionable whether CCs should be recommended for soils with a high clay content, where only moderate effects on $\mathrm{N}$ leaching can be expected (Myrbeck et al. 2012a) and where the risk of P leaching can even increase due to transport of dissolved P. However, a study by Neumann et al. (2012) on a Swedish sandy soil with a high risk of $\mathrm{N}$ leaching found that despite the presence of a frost-killed CC, where $\mathrm{P}$ release was probably substantial, P leaching was not increased. It was demonstrated by Roberson et al. (2007) that increased soil P status increases the part of leachable plant $\mathrm{P}$ that contributes to $\mathrm{P}$ losses. For soils with a filtering capacity for $\mathrm{P}$ in combination with a low degree of $\mathrm{P}$ saturation (e.g., sandy soils and soils with low surface runoff), CCs can probably be used without increasing the risk of $\mathrm{P}$ losses and at the same time effectively reduce $\mathrm{N}$ leaching.

Knowledge about the influence of CCs on $\mathrm{P}$ losses under Nordic conditions needs to be improved, especially regarding the complex role of roots in influencing soil $\mathrm{P}$ mobility and subsequent $\mathrm{P}$ losses. For example, plant roots may decrease the mobility of soil $\mathrm{P}$ by depleting the most mobile $\mathrm{P}$ fractions in the rhizosphere during uptake processes. However, roots may also enhance P mobility by changing the biochemical environment in the rhizosphere (Hinsinger 2001), and after decaying may leave behind macropores that act as a short-cut for $\mathrm{P}$ transport through the soil (Jarvis 2007). At the same time, a CC with a large proportion of its biomass in roots instead of shoots might avoid some surface losses after freezing/thawing events. For example, chicory had equal or lower losses than perennial ryegrass in the topsoil lysimeter study summarized in table 5 . Oilseed radish also performed well in that study and did not result in increased $\mathrm{P}$ leaching in the field study (table 4). Chicory has also been shown to have a positive effect on soil structure in Swedish field experiments (Löfkvist et al. 2005) and might therefore be an interesting crop from a multifunctional perspective in areas where reduced surface losses of P may be a result of improved infiltration capacity.

Use of CCs to reduce erosion may be interesting for Norway, where erosion is a major problem in many regions. With the increased efforts to reduce $\mathrm{N}$ leaching demanded by the EU Nitrates Directive, the use of CCs may increase again in Norway. However, at the moment the main focus is on mitigating $\mathrm{P}$ losses, and measures such as reduced tillage in autumn, grassed buffer zones and waterways, and constructed wetlands are encouraged rather than use of CCs. Studies in Norway have shown the importance of plowing in spring instead of autumn for reducing soil erosion and related $\mathrm{P}$ losses (Lundekvam and Skøien 1998), but there is still no evidence that CCs have any additional effects on erosion. The effect of CCs on $\mathrm{P}$ erosion is currently not included in the catchment model tool AGRICAT-P (Borch et al. 2010), which is used for modeling the effects of mitigation measures for soil and $\mathrm{P}$ reduced erosion.

In both Sweden and Norway, there has been declining interest in undersown grass CCs (with the area in Norway decreasing from 35,000 ha $[86,490 \mathrm{ac}]$ in 2002 to 4,400 ha $[10,870 \mathrm{ac}]$ in 2012). There can be different reasons for low interest among farmers (e.g., [1] difficulties with including CCs and their management in crop rotations, [2] low subsidy levels, [3] a more or less well-grounded fear of negative effects, and [4] lack of information). In a survey by the Swedish Board of Agriculture in 2010 examining Swedish farmers' opinions on CCs, reduced interest in CCs was found to be primarily related to subsidy level and the strict regulations on area required each year and time of termination of the CC. Other common reasons were the risk of decreased main crop yields, difficulties with harvesting, and the risk of the CC becoming a weed in the next crop. Many farmers prefer to use 
Table 5

The upper part of the table shows cover crop phosphorus $(\mathrm{P})$ content, change in concentration of water-extractable $\mathrm{P}$ in biomass in absolute ( $\mathrm{P}$ $\mathrm{kg}^{-1} \mathrm{dry}$ matter) and relative (\%) terms. The lower part of the table shows change in $\mathrm{P}$ concentration ( $\left.\mathrm{mg} \mathrm{L}^{-1}\right)$ in leachate from topsoil lysimeters with growing cover crops after freezing-thawing cycles (FTCs).

\begin{tabular}{|c|c|c|c|c|c|c|}
\hline \multirow[b]{2}{*}{ Description of study } & \multirow[b]{2}{*}{ Species } & \multicolumn{2}{|c|}{$\begin{array}{l}\text { Biomass at } \\
\text { harvest (kg ha-1) }\end{array}$} & \multirow{2}{*}{$\begin{array}{l}\text { P content } \\
\left(\mathrm{kg} \mathrm{ha}^{-1}\right)\end{array}$} & \multicolumn{2}{|c|}{$\begin{array}{l}\text { Change in total-P } \\
\text { concentration after FTCs } \\
\left(\mathrm{g} \mathrm{P} \mathrm{kg}^{-1}\right)\end{array}$} \\
\hline & & Shoot & Root & & or $\left(\mathrm{mg} \mathrm{L}^{-1}\right)$ & (\%) \\
\hline Extraction of $\mathrm{P}$ from & Cichorium intybus $L$. & 3,590 & 4,780 & 12.4 & +0.24 & $+2,400$ \\
\hline plant materials of & Dactylis glomerata L. & 1,770 & 1,890 & 6.4 & +0.27 & $+1,350$ \\
\hline $\mathrm{CC}$ grown in pure & Lolium perenne $L$. & 1,890 & 2,290 & 7.7 & +0.23 & $+1,150$ \\
\hline sand in greenhouse. & Trifolium pratense $L$. & 870 & 90 & 4.4 & n.d. & n.d. \\
\hline Water extractable $\mathrm{P}$ & Raphanus sativus var. Oleiformis & 5,270 & 2,520 & 17.5 & +0.39 & $+3,900$ \\
\hline (g P kg-1 dry matter & Phacelia tanacetifolia $L$. & 5,280 & 3,100 & 16.4 & +0.22 & $+2,200$ \\
\hline per extraction) was & Sinapis alba $L$. & 3,020 & 900 & 11.4 & +0.63 & +788 \\
\hline determined in plant & Raphanus sativus var. longipinnatus & 3,390 & 1,080 & 14.1 & +0.95 & $+3,167$ \\
\hline \multirow{2}{*}{\multicolumn{7}{|c|}{$\begin{array}{l}\text { materials with or } \\
\text { without } 4 \text { FTCs }\end{array}$}} \\
\hline & & & & & & \\
\hline \multicolumn{7}{|l|}{ (Liu et al. 2013). } \\
\hline Laboratory lysimeter & \multicolumn{6}{|c|}{ Sweden/L. Hammarby clay soil with high P content, 1 year } \\
\hline leaching study with & No CC & - & - & - & +0.13 & +18 \\
\hline intact plant materials & Cichorium intybus $L$. & 1,920 & 1,940 & 14.1 & +0.02 & +3 \\
\hline of CC grown in clay & Dactylis glomerata L. & 1,550 & 450 & 6.0 & +0.08 & +12 \\
\hline soils in the field. & Lolium perenne $L$. & 1,800 & 630 & 7.8 & +0.29 & +48 \\
\hline Mean concentrations & Trifolium pratense $L$. & 1,640 & 1,430 & 15.2 & +0.00 & 0 \\
\hline of $P\left(\mathrm{mg} \mathrm{L}^{-1}\right)$ in & Raphanus sativus var. oleiformis & 1,110 & 160 & 6.4 & +0.22 & +31 \\
\hline leachate were & Phacelia tanacetifolia $L$. & n.d. & n.d. & n.d. & n.d. & n.d. \\
\hline determined both & Sinapis alba $L$. & 1,210 & 330 & 7.1 & +0.04 & +6 \\
\hline before and after 7 FTCs & Raphanus sativus var. longipinnatus & 1,350 & 220 & 8.1 & -0.13 & -15 \\
\hline (Liu et al. 2014). & \multicolumn{6}{|c|}{ Sweden/L. Hammarby, Brunnby clay soils with medium P contents, 1 year each site } \\
\hline C. intybus, & No CC & - & - & - & +0.06 & +35 \\
\hline D. glomerata, & Cichorium intybus $L$. & 810 & 870 & 5.1 & -0.01 & -5 \\
\hline L. perenne, and & Dactylis glomerata L. & 1,440 & 450 & 5.0 & -0.06 & -21 \\
\hline T. pratense were & Lolium perenne L. & 1,250 & 640 & 4.3 & +0.09 & +47 \\
\hline undersown in spring & Trifolium pratense $L$. & 560 & 1,570 & 5.3 & +0.10 & +56 \\
\hline barley. R. sativus var. & Raphanus sativus var. oleiformis & 1,100 & 240 & 4.8 & -0.02 & -8 \\
\hline oleiformis, $P$. & Phacelia tanacetifolia $L$. & 1,360 & n.d. & 6.0 & -0.07 & -24 \\
\hline tanacetifolia, S. alba, & Sinapis alba $L$. & 1,270 & 390 & 5.2 & +0.07 & +41 \\
\hline and $R$. sativus var. & Raphanus sativus var. Iongipinnatus & 950 & 200 & 4.5 & -0.12 & -29 \\
\hline longipinnatus were & \multicolumn{6}{|c|}{ Sweden/Lanna clay soil with medium P contents, 3 years } \\
\hline sown after harvest of & No CC & - & - & - & +0.00 & 0 \\
\hline barley and were & Cichorium intybus $L$. & 120 & 170 & 1.0 & -0.02 & -12 \\
\hline fertilized with N 25 & Dactylis glomerata L. & 360 & 150 & 1.2 & +0.04 & +27 \\
\hline \multirow[t]{6}{*}{$\mathrm{kg} \mathrm{ha}^{-1}\left(22 \mathrm{lb} \mathrm{ac}^{-1}\right)$} & Lolium perenne L. & 560 & 190 & 1.9 & -0.02 & -10 \\
\hline & Trifolium pratense $L$. & 240 & 490 & 3.2 & +0.05 & +33 \\
\hline & Raphanus sativus var. oleiformis & 310 & 100 & 1.6 & +0.09 & +60 \\
\hline & Phacelia tanacetifolia $L$. & 600 & n.d. & 2.2 & +0.03 & +15 \\
\hline & Sinapis alba $L$. & 190 & 40 & 0.7 & -0.03 & -19 \\
\hline & Raphanus sativus var. Iongipinnatus & 250 & 50 & 1.5 & +0.02 & +13 \\
\hline
\end{tabular}

herbicide treatment of grass CCs in autumn in order to control weeds, including the CC itself, and the weather conditions after October 10 to 20, the current earliest limit for terminating a CC, are often doubtful. Thus, a wider time span for herbicide treat- ment was requested in the Swedish survey. In a study investigating the effect of glyphosate treatment in September to October, in combination with autumn or spring plowing, on two soils in Sweden (Aronsson et al. 2011), it was found that earlier herbicide application reduced the effect of the $\mathrm{CC}$ and that prolonging the $\mathrm{CC}$ growing season as much as possible was important for soils with a high risk of $\mathrm{N}$ leaching. The time of terminating $\mathrm{CC}$ growth on such soils will always require a compromise between different 
effects, such as low $\mathrm{N}$ leaching, control of weeds, and soil compaction aspects. In contrast to Norway and Sweden, the Finnish multipurpose perspective on CCs, including legumes for reducing use of fossil fuel-based fertilizers, in combination with higher subsidies and increased information, seems to be advantageous for the current CC implementation programs (Känkänen 2013). There has been a considerable increase in interest among Finnish farmers, resulting in the CC area increasing approximately 10 -fold for coming years.

In order to maintain farmers' interest and enable them to have a high frequency of CCs in their crop rotation, different options are needed. One example is the Danish solution with CCs before winter wheat (see above). Making a clearer distinction between different soils and climate zones, with differentiated subsidies, may also be a way to achieve efficient distribution of CCs in a region. If CCs are to be interesting to farmers, especially if they are not highly subsidized or mandatory, there should preferably be other obvious or detectable beneficial effects apart from reduced nutrient losses, especially in the short term. One could be the use of CCs for weed control in organic crop rotations. For example, the use of undersown CCs for suppression of perennial weeds has been studied in Sweden, where an undersown CC of perennial ryegrass and red clover suppressed the growth of couch grass (Elymus repens L.; Ringselle et al. 2015). Moreover, an undersown $\mathrm{CC}$ in combination with hoeing or mowing reduced $\mathrm{N}$ leaching substantially compared with conventional mechanical treatment of couch grass by repeated stubble cultivation (Aronsson et al. 2015). Another beneficial effect is residual $\mathrm{N}$ effect by use of legume CCs. However, the effect on reducing nitrate $\left(\mathrm{NO}_{3}\right)$ leaching is questionable if used in pure stands. Possible positive effects by CCs on soil structure (e.g., crucifers with deep tap roots) are interesting, since problems with soil compaction are a general concern in Scandinavia and Finland. The extensive root system of ryegrass may also provide rapid soil structure improvements. This was shown in a Norwegian study by Breland (1995), who found that a ridged plow furrow profile did not collapse during winter on plots with ryegrass undersown in spring wheat and observed a tendency for improved water stability of soil aggregates and aggregate size distribution compared with plots without CC and plots with white clover. The use of CCs for biomass production may contribute to intensification of cropping systems with combinations of biofuel crops and ordinary crops and associated low nutrient losses. For CCs, especially those which could be expected to be killed by frost, systems with CC harvesting would probably be preferable for both $\mathrm{N}$ and $\mathrm{P}$, in order to reduce the risk of losses from plant material. However, this would probably require intensified use of fertilizer. The use of fertilized intercrops for production of forage (e.g., ryegrasses and crucifers) was thoroughly examined in Denmark during 1960 to 1975 with respect to $\mathrm{N}$ utilization in relation to time of sowing (Hostrup 1970) and fertilizer application (Jacobsen and Bentholm 1977). Molinuevo-Salces et al. (2013) reported that crucifer CCs are promising sources of feedstock for manure-based biogas plants in Denmark. However, this requires a balance between different purposes and adaptation of the fertilization regime in order to keep the risk of $\mathrm{N}$ leaching as low as possible by maintaining high uptake efficiency by cover crops. Repeated use of CCs in Nordic cereal crop rotations may increase soil organic matter (Hansen et al. 2000a; Thomsen and Christensen 2004), which may increase soil fertility in the long term. However, this might have little impact for short-term decisions on farms. A recent study of some Swedish longterm CC field trials showed that perennial ryegrass CCs have a humification coefficient comparable to that of highly efficient organic amendments, such as farmyard manure and sewage sludge (Popleau et al. 2015). This means that growing perennial ryegrass CCs may not only be important for increased soil fertility in Nordic conditions, but possibly also for carbon (C) sequestration.

\section{Summary and Conclusions}

This review summarized current knowledge concerning use of CCs for reducing $\mathrm{N}$ leaching and $\mathrm{P}$ losses under the climate conditions of southern Scandinavia and Finland, where introducing CCs to reduce $\mathrm{N}$ leaching is a major component of agri-environmental programs. The field leaching studies reviewed showed that undersown ryegrass CCs are robust with respect to growth and reduction of $\mathrm{N}$ leaching, while crucifers sown after the main crop are less reliable as CCs due to the short time available for growth under cool climate conditions. The effect of $\mathrm{N}$ leaching varied between 11 experimental sites in the Nordic region, with an average reduction in $\mathrm{N}$ leaching of $43 \%$.

Less is known about the effect of CCs on $\mathrm{P}$ losses than $\mathrm{N}$ losses, but studies in lysimeter and field scale indicate that CCs do not substantially reduce total $\mathrm{P}$ losses by runoff and leaching. On the contrary, the prevailing climate conditions with freezing-thawing conditions during winter may pose an increased risk of losses of dissolved $\mathrm{P}$ from CC biomass if $\mathrm{P}$ is not efficiently adsorbed by the soil.

There is a clear need to identify CC systems and implementation strategies for appropriate distribution of CCs on different soils and regions. Differentiated recommendations are needed when the priority is to reduce $\mathrm{N}$ leaching or $\mathrm{P}$ losses, or both, or when CC effects on $\mathrm{N}$ leaching and $\mathrm{P}$ losses may be contradictory. For this, more knowledge is needed about the effect of CCs on $\mathrm{P}$ losses (e.g., the effect of species with different partitioning between shoot and root biomass and the effects of CC systems with harvest of biomass).

There is also a need for solutions for maintaining and increasing the frequency of CCs in crop rotations without negative and, if possible, with positive impacts on crop production. This requires a balance between effects on nutrient losses and other benefits of CCs. Benefits of CCs, such as improved soil fertility and soil structure, biomass harvest, green manure effects, weed control, and C sequestration, need to be quantified and promoted in order to maintain or increase interest in CC introduction among farmers and decision makers.

\section{References}

Andersen, A., and C.C. Olsen. 1993. Ryegrass as a catch crop in spring barley. Acta Agriculturae Scandinavica 43:218-230

Aronsson, H., J. Liu, E. Ekre, G. Torstensson, and E. Salomon. 2014. Effects of pig and dairy slurry application on N and $\mathrm{P}$ leaching from crop rotations with spring cereals and forage leys. Nutrient Cycling in Agroecosystems 98:281-293.

Aronsson, H., B. Ringselle, L. Andersson, and G. Bergkvist G. 2015. Combining mechanical control of couch grass (Elymus repens L.) with reduced tillage in early autumn and cover crops to decrease nitrogen and phosphorus leaching. Nutrient Cycling in Agroecosystems 102:383-396. 
Aronsson, H., and M. Stenberg. 2010. Leaching of nitrogen from a 3-yr grain crop rotation on a clay soil. Soil Use and Management 26:274-285.

Aronsson, H., M. Stenberg, and B. Ulén. 2011. Leaching of N, P and glyphosate from two soils after herbicide treatment and incorporation of a ryegrass catch crop Soil Use and Management 27:54-68.

Aronsson, H., and G. Torstensson. 1998. Measured and simulated availability and leaching of nitrogen associated with frequent use of catch crops. Soil Use and Management 14:6-13.

Aronsson, H., and G. Torstensson. 2003. HöstgrödorFånggrödor-Utlakning. Kvävedynamik och kväveutlakning i två växtföljder på moränlättlera i Skåne, 1999-2003 (Winter crops and cover crops-soil mineral $\mathrm{N}$ dynamics and $\mathrm{N}$ leaching from two crop rotations in south Sweden). Ekohydrologi 75, Swedish University of Agricultural Sciences, Uppsala, Sweden (in Swedish).

Aronsson, H., and G. Torstensson. 2009. Långsiktiga effekter av flytgödsel och fånggrödor på växtnäringsdynamik i marken och utlakning. Mellby försöksfält 1989-2009 (Long-term effects of applications of pig slurry on soil $\mathrm{N}$ dynamics and leaching. Mellby experimental field, 1989-2009). Ekohydrologi 114. Swedish University of Agricultural Sciences, Uppsala, Sweden (in Swedish).

Aronsson, H., G. Torstensson, and B. Lindén. 2003. Långliggande utlakningsförsök på lätt jord i Halland och Västergötland, 1998-2002 (Long-term field leaching experiments on two sandy soils in Sweden). Ekohydrologi 74, Swedish University of Agricultural Sciences, Uppsala, Sweden (in Swedish).

Askegaard, M., and J. Eriksen. 2008. Residual effect and leaching of $\mathrm{N}$ and $\mathrm{K}$ in cropping systems with clover and ryegrass catch crop on a coarse sand. Agriculture Ecosystems and Environment 123:99-108.

Bechmann, M. 2012. Effect of tillage on sediment and phosphorus losses from a field and a catchment in south eastern Norway. Acta Agriculturae Scandinavica Sect. B 62 Supplement 2:206-216

Bechmann, M.E., P.J.A. Kleinman, A.N. Sharpley, and L.S Saporito, L.S. 2005. Freeze-thaw effects on phosphorus loss in run-off from manures and catch-cropped soils. Journal of Environmental Quality 34:2301.

Bechmann, M., J. Deelstra, P. Stålnacke, H.O. Eggestad, L. Øygarden, and A. Pengerud. 2008. Monitoring catchment scale agricultural pollution in Norway: Policy instruments, implementation of mitigation methods and trends in nutrient and sediment losses. Environmental Science \& Policy 11:102-114.

Bechmann, M., and L. Øygarden. 2013. Suspended sediment concentration and losses. In Agriculture and Environment-Long-term Monitoring in Norway, eds. M. Bechmann and J. Deelstra, 231-249. Trondheim: Akademika Publishing.

Bechmann, M., A.F. Øgaard, P. Stålnacke, and B. Ulén. 2013. Phosphorus concentrations and losses. In Agriculture and Environment-Long-term Monitoring in Norway, eds. M. Bechmann and J. Deelstra, 213-229. Trondheim: Akademika Publishing.
Bergkvist, G., A. Adler, and M. Weih. 2010. Red fescue undersown in winter wheat suppresses Elytrigia repens. Weed Research 50:447-455.

Bergkvist, G., L. Ohlander, and T. Rydberg. 2002. Insådd av mellangrödor i höstsäd (Undersowing intercrops in winter cereals). Institutionen för ekologi och växtproduktionslära, Rapport 4. Swedish University of Agricultural Sciences, Uppsala, Sweden (in Swedish).

Bergkvist, G., M. Stenberg, J. Wetterlind, B. Båth, and S. Elfstrand. 2011. Clover crops under-sown in winter wheat increase yield of subsequent spring barley-Effect of $\mathrm{N}$ dose and companion grass. Field Crops Research 120:292-298.

Bergström, L., and W. E. Jokela. 2001. Ryegrass cover crop effects on nitrate leaching in spring barley fertilized with ${ }^{15} \mathrm{NH}_{4}{ }^{15} \mathrm{NO}_{3}$. Journal of Environmental Quality 30:1659-1667.

Bergström, L., and A. Shirmohammadi. 1999. Areal extent of preferential flow with profile depth in sand and clay monoliths. Journal of Soil Contamination 8:637-651.

Blombäck, K., H. Eckersten, E. Lewan, and H. Aronsson, 2003. Simulations of soil carbon and nitrogen dynamics during seven years in a catch crop experiment. Agricultural Systems 76(1):95-114.

Blombäck, K., H. Johnsson, H. Markensten, K. Mårtensson, C. Orback, K. Persson, and A. Lindsjö. 2014. Läckage av näringsämnen från svensk åkermark för år 2011 beräknat med PLC5-metodik (Leaching of $\mathrm{N}$ and $\mathrm{P}$ from Swedish arable land, calculated with PLC5 methodology). Working paper, Department of Soil and Environment, Swedish University of Agricultural Sciences, Uppsala, Sweden (in Swedish).

Boardman, J., and J. Poesen, eds. 2006. Soil erosion in Europe. London: Wiley \& Sons Ltd.

Borch, H., C. Farkas, A.F. Øgaard, and M. Bechmann. 2010 The AGRICAT-P model-A tool for modelling the mitigation effects of agricultural runoff in Norwegian catchments. Bioforsk Report 5(9).

Børgesen, S.D., P.N. Jensen, G. Blicher-Mathiesen, and K. Schelde. 2013. Udviklingen i kvælstofudvaskning og næringsstofoverskud fra dansk landbrug for perioden 2007-2011 (Development of $\mathrm{N}$ leaching from and nutrient balances in Danish agriculture). DCA rapport nr. 31. Aarhus University (in Danish).

Børresen, T., and G. Uhlen. 1991. Soil erosion and phosphorus losses in winter surface runoff in field lysimeters at Ås 1989-90. Norsk Landbruksforskning 5:47-54 (in Norwegian)

Brandsaeter, L.O., H. Heggen, H. Riley, E. Stubhaug, and T. Henriksen. 2008. Winter survival, biomass accumulation and $\mathrm{N}$ mineralization of winter annual and biennial legumes sown at various times of year in northern temperate regions. European Journal of Agronomy 28:437-448.

Breland,T.A. 1995. Green manuring with clover and ryegrass catch crops undersown in spring wheat: Effects on soil structure. Soil Use and Management 11:163-167.

Breland,T.A.1996a. Green manuring with clover and ryegrass catch crops undersown in small grains: Effects on soil mineral nitrogen in field and laboratory experiments. Acta Agriculturae Scandinavica, Section B 46:178-185.

Breland, T.A. 1996b. Green manuring with clover and ryegrass catch crops undersown in small grains: Crop development and yields. Acta Agriculturae Scandinavica, Section B 46:30-40.

Bye, A.S., P.A. Aarstad, A.I. Løvberget, and H. Høie. 2014 Jordbruk og miljø - Tilstand og utvikling 2013. Statistics Norway, Report 2014 10:1-134 (in Norwegian).

Dabney, S.M., J.A. Delgado, J.J Meisinger, H.H. Schomberg, M.A. Liebig, T. Kaspar, J. Mitchell, and W. Reeves. 2010 Using Cover crops and cropping systems for nitrogen management. In Advances in Nitrogen Management for Water Quality, eds. J.A. Delgado and R.F. Follett, 230281. Ankeny, IA: Soil and Water Conservation Society.

Dabney, S.M., J.A. Delgado, D.W. Reeves. 2001. Using winter cover crops to improve soil and water quality. Communication in Soil Science and Plant Analysis 32:1221-1250.

Djodjic, F., K. Börling, and L. Bergström. 2004. Phosphorus leaching in relation to soil type and soil phosphorus content. Journal of Environmental Quality 33:678-684.

Djurhuus, J. 1992. N-transformation and N-transport in a sandy loam and a coarse sandy soil cropped with spring barley. II. Nitrate leaching. Tidsskrift for Planteavl 96:137-152.

Djurhuus, J., and A.M. Lind. 1992. N-transformation and N-transport in a sandy loam and a coarse sandy soil cropped with spring barley. I. Beskrivelse af forsøgsarealerne, klima, planteproduktion og mineralsk $\mathrm{N}$ i jorden. Tidsskrift for Planteavls Specialserie. Beretning nr. S2213:1-48.

Engström, L., M. Stenberg, H. Aronsson, and B. Lindén. 2011. Reducing nitrate leaching after winter oilseed rape and peas in mild and cold winters. Agronomy for Sustainable Development 31:337-347.

Eriksen, J., M. Askegaard, and K. Søegaard. 2008. Residual effect and nitrate leaching in grass-arable rotations: Effect of grassland proportion, sward type and fertilizer history. Soil Use and Management 24:373-382.

European Commission. 2014a. The EU Water Framework Directive - Integrated river basin management for Europe. European Commission. 2014b. The Nitrates Directive. http://ec.europa.eu/environment/water/ water-nitrates/index_en.html.

Hansen, E.M., and J. Djurhuus. 1996. Nitrate leaching as affected by long-term $\mathrm{N}$ fertilization on a coarse sand. Soil Use and Management 12:199-204.

Hansen, E.M., and J. Djurhuus. 1997. Nitrate leaching as influenced by soil tillage and catch crop. Soil \& Tillage Research 41:203-219.

Hansen, E.M., J. Djurhuus, and K. Kristensen. 2000a. Nitrate leaching as affected by introduction or discontinuation of cover crop use. Journal of Environmental Quality 29:1110-1116.

Hansen, E.M., and I.K. Thomsen. 2013. Baggrundsnotat 1. Efterafgrøder (cover crops). In Udviklingen i kvælstofudvaskning og næringsstofoverskud fra dansk landbrug for perioden 2007-2011 (N leaching and nutrient surplus in Danish agriculture during the period 
2007-2011), eds. C.D. Børgesen, P.N Jensen, G. BlicherMathiesen, and K. Schelde. DCA rapport nr. 31. Aarhus University (in Danish).

Hansen, E.M., I.K.Thomsen, J. Djurhuus, A. Kyllingsbaek, V. Jørgensen, and K. Thorup-Kristensen. 2000b. Efterafgrøder (Cover crops). DJF rapport Markbrug nr 37. Danmarks jordbrugsforskning (in Danish).

Helcom (Helsinki Commission). 2011. The Fifth Baltic Sea Pollution Load Compilation (PLC-5). Baltic Sea Environ. Proc. 128. Baltic Marine Environ. Protect. Commission, Helsinki. http://helcom.fi/Documents/ Baltic\%20sea\%20action\%20plan/BSAP_Final.pdf.

Hinsinger, P. 2001. Bioavailability of soil inorganic P in the rhizosphere as affected by root-induced chemical changes: A review. Plant and Soil 237:173-195.

Hostrup, S. 1970. Fodder production with stubble crops. Species of cruciferaes, cereals and Italian ryegrass in pure stand and mixture. 1372. Beretning fra Statens Planteavlsforsøg (in Danish).

Jacobsen, A., and B.R. Bentholm. 1977. Efterafgrøders forfrugtsværdi ved stigende mængder kvælstof 1971-76 (Residual effects of cover crops at different applications of N). Oversigt over forsøg og undersøgelser i Landboog husmandsforeningerne 1976:141-144 (in Danish).

Jarvis, N.J. 2007. A review of non-equilibrium water flow and solute transport in soil macropores: Principles, controlling factors and consequences for water quality. European Journal of Soil Science 58:523-546.

Jensen, E.S. 1991. Nitrogen accumulation and residual effects of nitrogen catch crops. Acta Agriculturae Scandinavica 4:333-344.

Johnsson, H., M. Larsson, A. Lindsjö, K. Mårtensson, K. Persson, and G. Torstensson. 2008. Läckage av näringsämnen från svensk åkermark. Beräkningar av normalläckage av kväve och fosfor för 1995 och 2005 (Nutrient leaching from Swedish arable land, calculations for 1995 and 2005). Swedish Environmental Protection Board, report 5823 (in Swedish with English summary).

Karlsson-Strese, E.-M., M. Umaerus, and I. Rydberg. 1996. Strategy for catch crop development. 1. Hypothetical ideotype and screening of species. Acta Agriculturae Scandinavica 46:106-111.

Känkänen, H. 2013. Proceedings of the first Legume Society Conference, 2013: A Legume Odyssey, 9-11 May 2013, Novi Sad, Serbia, eds. A. Mikic, D. Rubiales, and V. Dordevic, p. 231. International Legume Society, Institute of Field and Vegetable Crops.

Känkänen, H., and C. Eriksson. 2007. Effects of undersown crops on soil mineral $\mathrm{N}$ and grain yield of spring barley. European Journal of Agronomy 27:25-34.

Känkänen, H., A. Kanjas, T. Mela, U. Nikunen, H. Tuuri, and M. Vuorinen. 1998. Timing incorporation of different green manure crops to minimize the risk of nitrogen leaching. Agricultural and Food Science in Finland 7:553-567.

Känkänen, H., C. Eriksson, M. Räkköläinen, and M. Vuorinen. 2001. Effect of annually repeated undersowing on cereal grain yield. Agricultural and Food Science in Finland 10:197-208.
Känkänen, H., C. Eriksson, M. Räkköläinen, and M. Vuorinen. 2003. Soil nitrate as influenced by annually undersown cover crops in spring cereals. Agricultural and Food Science in Finland 12:165-176.

Känkänen, H., A. Suokannas, K. Tiilikkala, and A. Nykänen. 2013. Biologinen typensidonta fossilisen energian säästäjänä (Reducing use of fossil energy by biological $\mathrm{N}$ fixation). MTT rapportti 76 (in Finnish with English summary).

Kirkegaard, J., O. Christen, J. Krupinsky, and D. Layzell. 2008. Break crop benefits in temperate wheat production. Field Crops Research 107:185-195.

Köppen, W. 1936. Das geographisce System der Klimate. In Handbuch der Klimatologie, 1. C. Gebr, Borntraeger, eds. W. Köppen and G. Geiger, 1-44. Berlin: Verlag von Gebrüder Borntraeger.

Lemola, R., E. Turtola, and C. Eriksson. 2000. Undersowing Italian ryegrass diminishes nitrogen leaching from spring barley. Agricultural and Food Science in Finland 9:201-215.

Lemola, R., E. Valkama, T. Suojala-Ahlfors, H. Känkänen, J. Heikkinen, and E. Turtola. 2014. Alus- ja kerääjäkasvien potentiaali vähentää maatalouden aiheuttamaa typpikuormitusta. In Kerääjäkasvit: hyötyä viljelijälle ja ympäristölle (The potential of undersown and cover crops to reduce $\mathrm{N}$ leaching from agriculture. In Cover crops: Benefit for farmer and environment). TEHO Plus -hankkeen julkaisu 6/2014:2-25 (in Finnish).

Lewan, E. 1994. Effects of a catch crop on leaching of nitrogen from a sandy loam: Simulations and measurements. Plant and Soil 166:137-152.

Lindén, B., H. Aronsson, L. Engström, G. Torstensson, and T. Rydberg. 2006. Kvävemineralisering och utlakning av kväve och fosfor på en lerjord vid Lanna iVästergötland ( $\mathrm{N}$ mineralization and leaching of $\mathrm{N}$ and $\mathrm{P}$ on a clay soil). Ekohydrologi nr 91, Swedish University of Agricultural Sciences, Uppsala, Sweden (in Swedish).

Lindén, B., H. Aronsson, A. Gustafson, and G. Torstensson. 1993. Fånggrödor, direktsådd och delad kvävegiva -studier av kväveverkan och utlakning i olika odlingssystem i ett lerjordsförsök i Västergötland (Cover crops, direct drilling and split N-doses. Studies of $\mathrm{N}$ effects on crops and leaching on a clay soil). Ekohydrologi 33, Swedish University of Agricultural Sciences, Uppsala, Sweden (in Swedish).

Lindén, B., L. Engström, H. Aronsson, K. Hessel Tjell, A. Gustafson, M. Stenberg, and T. Rydberg. 1999. Kvävemineralisering under olika årstider och utlakning på en mojord i Västergötland ( $\mathrm{N}$ mineralization an leaching during different seasons on a sandy soil). Ekohydrologi 51, Swedish University of Agricultural Sciences, Uppsala, Sweden (in Swedish).

Lindén,B.,J.Roland, and R.Tunared.2000.Höstsäds kväveupptag under hösten ( $\mathrm{N}$ uptake in winter cereals during autumn). Rapport 5, Institutionen för jordbruksvetenskap, Swedish University of Agricultural Sciences, Skara, Sweden (in Swedish with English summary).

Lindén, B., and B. Wallgren. 1993. Nitrogen mineralization after leys ploughed in early or late autumn. Swedish Journal of Agricultural Research 23:77-89.
Liu, J., H. Aronsson, K. Blombäck, K. Persson, and L. Bergström. 2012. Long-term measurements and model simulations of phosphorus leaching from a manured sandy soil. Journal of Soil and Water Conservation 67(2):101-110, doi:10.2489/jswc.67.2.101.

Liu, J., R. Khalaf, B. Ulén, and G. Bergkvist. 2013. Potential phosphorus release from catch crop shoots and roots after freezing-thawing. Plant and Soil 371:543-557.

Liu, J., B. Ulén, G. Bergkvist, and H. Aronsson. 2014. Freezing-thawing effects on phosphorus leaching from catch crops. Nutrient Cycling in Agroecosystems 99:17-30.

Lundekvam, H., and S. Skøien. 1998. Soil erosion in Norway. An overview of measurements from soil loss plots. Soil Use and Management 14:84-89.

Lyngstad, I., and T. Børresen. 1996. Effects of undersown cover crops on yield and soil mineral nitrogen in cereal production in southeast Norway. Norwegian Journal of Agricultural Sciences 10:55-70.

Löfkvist, J., W.R. Whalley, and L.J. Clark. 2005. A rapid screening method for good root-penetration ability: Comparison of species with very different root morphology. Acta Agriculturae Scandinavica Section B 55(2):120-124.

Molinuevo-Salces, B., S.U Larsen, B.K. Ahring, and H. Uellendahl. 2013. Biogas production from catch crops: Evaluation of biomass yield and methane potential of catch crops in organic crop rotations. Biomass and Bioenergy 59:285-292.

Möller, K., and H.J. Reents. 2009. Effects of various cover crops after peas on nitrate leaching and nitrogen supply to succeeding winter wheat or potato crops. Journal of Plant Nutrition and Soil Science 172:277-287.

Munkholm, L.J., and E.M. Hansen. 2012. Catch crop biomass production, nitrogen uptake and root development under different tillage systems. Soil Use and Management 28:517-529.

Myrbeck, Å., M. Stenberg, J. Arvidsson, and T. Rydberg. 2012a. Effects of autumn tillage of clay soil on mineral $\mathrm{N}$ content, spring cereal yield and soil structure over time. European Journal of Agronomy 34(1):96-104.

Myrbeck, Å., M. Stenberg, and T. Rydberg. 2012b. Establishment of winter wheat-strategies for reducing the risk of nitrogen leaching in a cool-temperate region. Soil \& Tillage Research 120:25-31.

Myrbeck, Å., J. Arvidsson, and T. Keller. 2014. Effect of time of autumn and primary tillage on soil structure, grain yield and risk of nitrogen leaching in two Swedish clay soils. Acta Agriculturae Scandinavica. Section B 64(1):33-44.

Neumann, A., G. Torstensson, and H. Aronsson. 2011. Losses of nitrogen and phosphorus via the drainage system from organic crop rotations with and without livestock on a clay soil in south-west Sweden. Organic Agriculture 1:217-229.

Neumann, A., G. Torstensson, and H. Aronsson. 2012. Nitrogen and phosphorus leaching losses from potatoes with different harvest times and following crops. Field Crops Research 133:130-138. 
Nilsdotter-Linde, N., G. Bergkvist, and L. Ohlander. 1994 Species and varieties of undersown catch crops in spring barley. In Proceedings from NJF seminar no 245 "The use of catch or cover crops to reduce leaching and erosion." Knivsta, Sweden, 3-4 October 1994, 236-241.

NIVA. 2013. TEOTIL - Kildefordelte tilførsler av nitrogen og fosfor til norske kystområder i 2012 (Source apportionment of $\mathrm{N}$ and $\mathrm{P}$ load on coastal waters in Norway). Norwegian institute for water research, Notat (in Norwegian).

Øgaard, A.F. 2015. Freezing and thawing effects on phosphorus release from grass and cover crop species. Acta Agriculturae Scandinavica, Section B 65(6):529-536.

Ohlander, L., G. Bergkvist, F. Stendahl, and M. Kvist. 1996. Yield of catch crops and spring barley as affected by time of undersowing. Acta Agriculturae Scandinavica 46:161-168.

Pedersen, J.B., and Pedersen, C. 2013. Efter- og Mellemafgrøder (Cover crops and intercrops). In Oversigt over Landsforsøgene 2013, 195-217, Videncentret for Landbrug, Skejby, Denmark (in Danish).

Poeplau, C., H. Aronsson, Å. Myrbeck, and T. Kätterer. 2015. Effect of perennial ryegrass cover crop on soil organic carbon stocks in southern Sweden. Geoderma Regional 4:126-133.

Power, J.F., and J.A. Zachariassen. 1993. Relative nitrogen utilization by legume cover crop species at three soil temperatures. Agronomy Journal 85:134-140.

Ranells, N.N., and M.G. Wagger. 1997. Grass-legume bicultures as winter annual cover crops. Agronomy Journal 89:659-665

Riddle, M.U., and L. Bergström. 2013. Phosphorus leaching from two soils with catch crops exposed to freeze-thaw cycles. Agronomy Journal 105:803-811.

Ringselle, B., G. Bergkvist, H. Aronsson, and L. Andersson. 2015. Under-sown cover crops and post-harvest mowing as measures to control Elymus repens. Weed Research 55(3):309-319.

Roberson, T., L.G. Bundy, and T.W. Andraski. 2007. Freezing and drying effects on potential plant contributions to phosphorus in runoff. Journal of Environmental Quality 36:532-539.

Salo, T., and E.Turtola. 2006. Nitrogen balance as an indicator of nitrogen leaching in Finland. Agriculture, Ecosystems and Environment 113:98-107.

Simmelsgaard, S.E. 1991. Slutrapport for projektet: Kvælstofudvaskning efter udbringning af kartoffelfrugtsaft. (Final report of the project: $\mathrm{N}$ leaching after application of potato juice) Statens Planteavlsforsøg. Working paper, Aarhus University.

Stenberg, M., H. Aronsson, B. Lindén, T. Rydberg, and A. Gustafson. 1999. Soil mineral nitrogen and nitrate leaching losses in soil tillage systems combined with a catch crop. Soil and Tillage Research 50:115-125.

Sturite, I., T.M. Henriksen, and T.A. Breland. 2007. Winter losses of nitrogen and phosphorus from Italian ryegrass, meadow fescue and white clover in a northern temperate climate. Agriculture Ecosystems and Environment 120:280-290.
Thomsen, I.K., and B.T Christensen. 2004. Yields of wheat and soil carbon and nitrogen contents following longterm incorporation of barley straw and ryegrass catch crops. Soil Use and Management 20:432-438.

Thomsen, I.K., J.F. Hansen,V. Kjellerup, and B.T. Christensen. 1993. Effects of cropping system and rates of nitrogen in animal slurry and mineral fertilizer on nitrate leaching from a sandy loam. Soil Use and Management 9:53-58.

Thorup-Kristensen, K. 1993. The effect of nitrogen catch crops on the nitrogen nutrition of a succeeding crop. I. Effects through mineralization and pre-emptive competition. Acta Agriculturae Scandinavica 43:74-81.

Thorup-Kristensen, K. 1994. The effect of nitrogen catch crop species on nitrogen nutrition of succeeding crops. Fertilizer Research 37:227-234.

Thorup-Kristensen, K. J., Magid, and L. Stoumann Jensen. 2003. Catch crops and green manures as biological tools in nitrogen management in temperate zones. In Advances in Agronomy, ed. D. Sparks 79:227-302.

Thorup-Kristensen, K., and D.B. Dressbøll. 2010. Incorporation time of nitrogen catch crops influences the $\mathrm{N}$ effect for the succeeding crop. Soil Use and Management 26:27-35.

Thomsen, I.K., and E.M. Hansen. 2014. Cover crop growth and impact on $\mathrm{N}$ leaching as affected by pre- and postharvest sowing and time of incorporation. Soil Use and Management 30:48-57.

Tike. 2011. Agricultural statistics. Farm Structure Survey, Agricultural Census 2010-Farmland management. http://stat.luke.fi/.

Torstensson, G. 1998. Nitrogen delivery and utilization by subsequent crops after incorporation of leys with different plant composition. Biological Agriculture and Horticulture 16:129-143.

Torstensson, G., and H. Aronsson. 2000. Nitrogen leaching and crop availability in manured catch crop systems. Nutrient Cycling in Agroecosystems 56(2):139-152.

Torstensson, G., H. Aronsson, and L. Bergström. 2006. Nutrient use efficiencies and leaching of organic and conventional cropping systems in Sweden. Agronomy Journal 98:603-615.

Turtola, E., and A. Jaakkola. 1995. Loss of phosphorus by surface runoff and leaching from a heavy clay soil under barley and grass ley in Finland. Acta Agriculturae Scandinavica, Section B 45:159-165.

Uhlen, G., L. Bakken, and L.E. Haugen. 1996. Nutrient and water balances in lysimeter experiments. II. Nitrogen and mineral leaching and balances. Norwegian Journal of Agricultural Sciences 10:339-354.

Ulén, B. 1997. Nutrient losses by surface runoff from winter green and spring-ploughed soil in the south of Sweden. Soil \& Tillage Research 44:165-177.

Ulén, B., H. Aronsson, M. Bechmann, T. Krogstad, L. Øygarden, and M. Stenberg. 2010. Soil tillage measures to control phosphorus loss and potential side-effects: A Scandinavian review. Soil Use and Management 26:94-107.

Ulén, B., and T. Kalisky. 2005. Water erosion and phosphorus problems in an agricultural catchment-Need for natural research for implementation of the EU Water Framework Directive. Environmental Science \& Policy 8:477-484.

Uusi-Kämppä, J. 2008. Evaluating vegetated buffer zones for phosphorus retention in cereal and grass production. In Proceedings NJF Seminar 401 (Phosphorous management in Nordic-Baltic agriculture-reconciling productivity and environmental protection, ed. G.H. Rubæk), Uppsala, Sweden, 22-23 September, 2008, NJF Report 4:68-73.

Valkama, E., R. Lemola, H. Känkänen, and E. Turtola. 2015. Meta-analysis of the effects of undersown catch crops on nitrogen leaching loss and grain yields in the Nordic countries. Agriculture, Ecosystems and Environment 203:93-101.

Vuorenmaa J., S. Rekolainen, A. Lepisto, K. Kenttamies, and P. Kauppila. 2002. Losses of nitrogen and phosphorus from agricultural and forest areas in Finland during the 1980s and 1990s. Environmental Monitoring and Assessment 76:213-248.

Wallgren, B., and B. Lindén. 1994. Effects of catch crops and ploughing times on soil mineral nitrogen. Swedish Journal of Agricultural Research 24:67-75.

Wetterlind, J., B. Stenberg, M. Stenberg, and B. Lindén. 2006. Mouldboard ploughing in early autumn on clay soils_ - risk assessment of nitrogen leaching. Division of precision agriculture, Report 6, Swedish University of Agricultural Sciences, Skara, Sweden (in Swedish with English summary). 